

\title{
Influence of sexual dimorphism on stable isotopes and trace element concentrations in the greater hooked squid Moroteuthopsis ingens from New Zealand waters
}

Alexandra Lischka, H. Braid, Yves Cherel, Kathrin Bolstad, T. Lacoue-Labarthe, Paco Bustamante

\section{To cite this version:}

Alexandra Lischka, H. Braid, Yves Cherel, Kathrin Bolstad, T. Lacoue-Labarthe, et al.. Influence of sexual dimorphism on stable isotopes and trace element concentrations in the greater hooked squid Moroteuthopsis ingens from New Zealand waters. Marine Environmental Research, 2020, 159, pp.104976. 10.1016/j.marenvres.2020.104976 . hal-02546145

\section{HAL Id: hal-02546145 \\ https://hal.science/hal-02546145}

Submitted on 17 Apr 2020

HAL is a multi-disciplinary open access archive for the deposit and dissemination of scientific research documents, whether they are published or not. The documents may come from teaching and research institutions in France or abroad, or from public or private research centers.
L'archive ouverte pluridisciplinaire HAL, est destinée au dépôt et à la diffusion de documents scientifiques de niveau recherche, publiés ou non, émanant des établissements d'enseignement et de recherche français ou étrangers, des laboratoires publics ou privés. 


\section{Influence of sexual dimorphism on stable isotopes and trace element concentrations in the} greater hooked squid Moroteuthopsis ingens from New Zealand waters

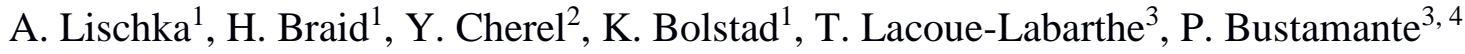

${ }^{1}$ AUT Lab for Cephalopod Ecology \& Systematics, School of Science, Auckland University of Technology, Private Bag 92006, 1142, Auckland, New Zealand

${ }^{2}$ Centre d'Etudes Biologiques de Chizé (CEBC), UMR 7372 CNRS-La Rochelle Université, 79360 Villiers-en-Bois, France

${ }^{3}$ Littoral Environnement et Sociétés (LIENSs), UMR 7266 CNRS-La Rochelle Université, 2 rue Olympe de Gouges, 17000 La Rochelle, France

${ }^{4}$ Institut Universitaire de France (IUF), 1 rue Descartes 75005 Paris, France

*corresponding author: alexandralischka90@gmail.com 


\begin{abstract}
The Chatham Rise, one of the highest offshore-primary production regions in New Zealand waters, hosts a great abundance and diversity of deep-sea cephalopods including the greater hooked squid, Moroteuthopsis ingens. Stable isotope ratios of carbon $\left(\delta^{13} \mathrm{C}\right)$ and nitrogen $\left(\delta^{15} \mathrm{~N}\right)$ and trace element concentrations ( $\mathrm{Ag}, \mathrm{As}, \mathrm{Cd}, \mathrm{Co}, \mathrm{Cr}, \mathrm{Cu}, \mathrm{Fe}, \mathrm{Hg}, \mathrm{Ni}, \mathrm{Pb}, \mathrm{Se}, \mathrm{V}$, and $\mathrm{Zn}$ ) were assessed in female and male specimens of different size classes (89-563 mm mantle length). Values of $\delta^{13} \mathrm{C}$ and $\delta^{15} \mathrm{~N}$ were overall higher in females and $\delta^{13} \mathrm{C}$ was further influenced by size and sex. Both muscular mantle (the largest fraction of the total body mass) and digestive gland (the known main storage organ for Ag, $\mathrm{Cd}, \mathrm{Cu}$ and $\mathrm{Zn}$ in many cephalopods) tissues were analysed. Higher levels of $\mathrm{Cd}$ were observed in males than in females. A positive effect was found between size and $\mathrm{Hg}$ concentrations, which could be related to the ontogenetic descent of larger specimens into deeper waters, where they are exposed to higher $\mathrm{Hg}$ concentrations, and/or dietary shifts toward $\mathrm{Hg}$-enriched prey with increasing size. This study provides trace element data for this abundant and ecologically important species, and further reveals higher trace element concentrations (especially $\mathrm{Hg}$ ) in $M$. ingens from the Chatham Rise, compared to specimens from the sub-Antarctic zone.
\end{abstract}

Keywords: Cephalopods; biomonitoring; bioaccumulation; metals; Onychoteuthidae 


\section{Introduction}

Trace elements occur naturally at varying concentrations in the marine environment. They are persistent and do not degrade but are taken up by marine organisms, and their biogeochemical cycling can be strongly influenced by their transfer through food webs (Wang and Fisher, 1998). Concentrations of trace elements recorded in biota are influenced by both natural (e.g., geothermal, volcanic activity or upwelling events; Langston, 2017) and anthropogenic sources (e.g. agriculture, industrial production or mining; Tchounwou et al., 2012). High concentrations of $\mathrm{Cd}$ and $\mathrm{Hg}$ have been previously measured in marine organisms (Bryan, 1984; Eisler, 2009), even from remote or pristine environments (Bustamante et al. 2003, Cipro et al. 2018). For example, anomalously high Cd concentrations were reported from polar oceans (Frew, 1995; Gault-Ringold et al., 2012), and also found in high-latitude biota (e.g., Jöst and Zauke, 2008; Keil et al., 2008; Petri and Zauke, 1993; Zauke et al., 1999). In the case of $\mathrm{Hg}$, which mainly occurs in marine organisms as methyl-Hg (its organic form), biomagnification has been reported along food webs, reaching highest concentrations in apex predators (Cherel et al., 2018; Eagles-Smith et al. 2018; Fisher and Reinfelder, 1995; Rainbow, 1995).

Cephalopods are crucial members of the pelagic food webs, as they are consumed by a variety of apex predators (Boyle and Rodhouse, 2005; de la Chesnais et al., 2019), and are also the most frequently observed predators in bathypelagic and mesopelagic food webs themselves (Choy et al., 2017). Cephalopods have the ability to accumulate high concentrations of trace elements, particularly $\mathrm{Ag}, \mathrm{Cd}, \mathrm{Cu}$, and $\mathrm{Zn}$, in their digestive glands (e.g, Martin and Flegal, 1975; Miramand et al., 2006; Miramand and Bentley, 1992), and have been suggested as a major vector for Cd to their predators (Bustamante et al., 1998a). 
The warty or greater hooked squid, Moroteuthopsis ingens (Smith, 1881), formerly known as Moroteuthis or Onykia ingens (the genus placement recently changed; Bolstad et al., 2018), is a deepsea sub-Antarctic species that shows a strong sexual dimorphism, with females reaching about five times the weight of males (Bolstad, 2006; Jackson, 1995). Its high abundance and its central position in marine food webs highlight its ecological importance in sub-Antarctic waters. Indeed, $M$. ingens is a mid-trophic species, and its diet shifts with ontogeny (Arkhipkin and Laptikhovsky, 2010). In early life stages it consumes planktonic crustaceans and small Doryteuthis gahi (formerly Loligo gahi); later it feeds primarily on squid (D. gahi and Histioteuthis atlantica), followed by myctophid fish (Gymnoscopelus sp., Salilota australis), crustaceans (Munidae, Euphausiacea), and chaetognaths (Cherel and Duhamel, 2003; McArthur et al., 2003; Rosas-Luis et al., 2014). In addition, cannibalism has been reported in this species (Ibánez and Keyl, 2010). Beside its role as a predator, a variety of marine animals feed on $M$. ingens, such as the wandering albatross, Diomedea exulans (Cherel et al., 2017), Patagonian toothfish, Dissostichus eleginoides (Xavier et al., 2002), southern elephant seal, Mirounga leonina (Green and Burton, 1993), and sperm whale, Physeter macrocephalus (Clarke and Roper, 1998). Finally, Moroteuthopsis ingens is a frequent bycatch species in commercial trawling (Cherel and Duhamel, 2003; Jackson, 1995), but without commercial interest due to the stored ammonium in its tissues used for buoyancy, making it unpalatable to humans (Jackson et al., 2000; Lu and Williams, 1994).

Within New Zealand waters, $M$. ingens has been reported between the subtropical and Antarctic polar fronts, and in high abundances on the Chatham Rise (Jackson, 1995, Jackson et al., 1998; Fig 1.) This rise is a submarine plateau extending about $800 \mathrm{~km}$ eastward from New Zealand's South Island (Carter, 1980), and is overlain by the southern subtropical front, where warmer northern waters mix with cooler southern waters. This area has New Zealand's highest offshore primary production and biomass (Murphy et al., 2001; Probert and McKnight, 1993). A diverse assemblage of cephalopods 
occurs on the Chatham Rise, some in considerable abundance, including the southern arrow squid, Nototodarus sloanii, the red squid, Ommastrephes bartramii, the giant squid, Architeuthis dux, the rugose hooked squid, Onykia robsoni, as well as M. ingens (Pinkerton, 2011).

To date, studies on trace element concentrations from New Zealand waters have primarily focussed on either commercially important species, such as arrow squids, Nototodarus spp. (Lischka et al., 2019b, 2020), greenshell mussels, Perna canaliculus (Whyte et al., 2009), finfish species such as snapper, Chrysophrys auratus (Brooks and Rumsey, 1974), and seabirds such as grey-faced petrels, Pterodroma gouldi (Lyver et al., 2017). Trace element concentrations in cephalopods, including $M$. ingens, remain understudied despite their ecological importance as both predator and prey. Currently, only a single study has been undertaken on trace elements in this species from New Zealand waters using beaks as environmental tracers (Northern et al., 2019), but no studies have examined contaminant concentrations in the soft parts (including the digestive gland and the mantle tissue) which represent most of the squid's biomass. The digestive gland is the main storage organ for a variety of trace elements, containing up to $98 \%$ of the whole body burden of $\mathrm{Cd}$ in squids (Bustamante et al. 2002a). The muscular mantle tissue represents approximately half of the total weight of the squid and has been reported to contain up to $95 \%$ of the whole $\mathrm{Hg}$ body burden in cephalopods (Bustamante et al. 2006). Although the digestive gland and mantle tissue have been analysed for trace elements in $M$. ingens from other parts of the Southern Ocean (south of the Subtropical Front; McArthur et al., 2003, Cipro et al. 2018), comparative data from New Zealand are needed in order to understand the cycling of certain elements within different food webs and the potential role of this squid as a vector of trace elements.

In this context, this study aims to provide information on trace element levels and distribution in $M$. ingens tissues and to analyse the possible influence of the sexual dimorphism on the observed 
concentration patterns. Our specific objectives were to 1) assess the trophic ecology, trophic magnification and feeding habitat of $M$. ingens through stable isotope analysis of nitrogen $\left(\delta^{15} \mathrm{~N}\right)$ and carbon $\left(\delta^{13} \mathrm{C}\right)$, respectively; 2) analyse trace element concentrations in the digestive gland and the muscular mantle tissue; 3) contrast the trace element concentrations of $M$. ingens from New Zealand waters with specimens from other areas in the Southern Ocean; and 4) compare the trace element concentrations of $M$. ingens, as an ammoniacal species, with those observed in $N$. sloanii, a cooccurring non-ammoniacal species, thereby examining potential differences in the physiological strategies for trace element storage.

Material and Methods

\section{Sample collection}

All specimens of $M$. ingens were opportunistically collected during a trawl survey (using a hoki bottom trawl) in January and February 2016 by the Research Vessel Tangaroa (National Institute for Water and Atmospheric Research, Ltd. [NIWA]). Trawling depths ranged from 800 to $1300 \mathrm{~m}$ on the Chatham Rise in New Zealand $\left(42^{\circ} 55^{\prime}\right.$ to $45^{\circ} 07^{\prime} \mathrm{S}$, and $174^{\circ} 15^{\prime}$ to $179^{\circ} 58^{\prime}$ E, Fig. 1). In total, 84 specimens, including 25 males (89-470 mm in mantle length [ML]) and 59 females (98-563 mm ML, with $n=15>400 \mathrm{~mm}$ ML; Table S1) were collected from 26 stations and frozen at $-20^{\circ} \mathrm{C}$ until examination. Upon dissection, specimens were sexed, measured and weighed.

\section{Stable isotope analysis}

Stable isotope values of carbon $\left(\delta^{13} \mathrm{C}\right)$ and nitrogen $\left(\delta^{15} \mathrm{~N}\right)$ were analysed in freeze-dried mantle tissue (0.2-0.4 mg) with a continuous flow mass spectrometer (Delta V Plus with a Conflo IV interface, Thermo Scientific, Bremen, Germany) coupled to an elemental analyser (Flash 2000, Thermo Scientific, Milan, Italy). Results are expressed in the \%o unit notation as deviations from standards 
(Vienna Pee Dee Belemnite for $\delta^{13} \mathrm{C}$ and $\mathrm{N}_{2}$ in air for $\delta^{15} \mathrm{~N}$ ) following the formula: $\delta^{13} \mathrm{C}$ or $\delta^{15} \mathrm{~N}=$ $\left[\left(R_{\text {sample }} / R_{\text {standard }}\right)-1\right] \times 10^{3}$, where $\mathrm{R}$ is ${ }^{13} \mathrm{C} /{ }^{12} \mathrm{C}$ or ${ }^{15} \mathrm{~N} /{ }^{14} \mathrm{~N}$, respectively. The analytical precision, based on internal laboratory standards (acetanilide and peptone), was $<0.10 \%$ for $\delta^{13} \mathrm{C}$ and $<0.15 \%$ o for $\delta^{15} \mathrm{~N}$.

\section{Trace element analysis}

Freeze-dried tissue samples of digestive gland and mantle tissue were homogenised. Tissue samples ( 200 mg dry weight [dw]) were digested overnight in a 3:1 mixture of $65 \% \mathrm{HNO}_{3}$ (Merck, suprapur quality) and 37\% $\mathrm{HCl}$ (Merck, suprapur quality). Mineralisation followed by heating the samples for $30 \mathrm{~min}$ in a Milestone microwave (maximum temperature of $105^{\circ} \mathrm{C}$ ). Concentrations of 12 trace elements ( $\mathrm{Ag}, \mathrm{As}, \mathrm{Cd}, \mathrm{Co}, \mathrm{Cr}, \mathrm{Cu}, \mathrm{Fe}, \mathrm{Ni}, \mathrm{Pb}, \mathrm{Se}, \mathrm{V}$, and $\mathrm{Zn}$ ) were measured by inductively coupled plasma mass spectroscopy (ICP-MS) with a Thermo Fisher Scientific X Series 2 and optical emission spectroscopy (OES) with a Varian Vista-Pro following Lucia et al (2016). Procedural blanks and certified reference materials were treated and analysed in the same way as the other samples. Element recoveries ranged from 91 to $118 \%(n=9)$ for lobster hepatopancreas (TORT-3, National Research Council, Canada NRCC) and from 78 to $107 \%$ for dogfish liver (DOLT-5, NRCC). The detection limits for $\mathrm{Ag}, \mathrm{Cd}, \mathrm{Co}, \mathrm{Mn}$ and $\mathrm{Pb}$ were $0.01 \mu \mathrm{g} \mathrm{g}^{-1}$; As was $10.22 \mu \mathrm{g} \mathrm{g}^{-1}$; Cr was $0.1 \mu \mathrm{g} \mathrm{g}^{-1} ; \mathrm{Fe}$ and Zn were $4.09 \mu \mathrm{g} \mathrm{g}^{-1}$; $\mathrm{Cu}$ was $1.02 \mu \mathrm{g} \mathrm{g}^{-1}$; Ni was $0.04 \mu \mathrm{g} \mathrm{g}^{-1}$; Se was $20.43 \mu \mathrm{g} \mathrm{g}^{-1}$ and $\mathrm{V}$ was $2.04 \mu \mathrm{g}$ $\mathrm{g}^{-1}$ (based on $200 \mathrm{mg}$ of sample material diluted in a volume of $50 \mathrm{ml}$ ). Results for trace element concentrations are further expressed in $\mu \mathrm{g} \mathrm{g}^{-1} \mathrm{dw}$.

Mercury concentrations were measured by an Advanced Mercury Analyser (ALTEC AMA 254) for dried, homogenised digestive gland and mantle tissue (1-2 mg dw) as described in Bustamante et al. (2006). All analyses were repeated two or three times until a relative standard deviation $<10 \%$ was obtained. The accuracy was controlled by the analysis of certified reference material (CRM) of 
DOLT-5, with recoveries of $98 \%(n=18)$. The detection limit of the AMA was $0.05 \mathrm{ng}$.

\section{Interaction between $\mathrm{Hg}$ and $\mathrm{Se}$}

Selenium has been suggested to have a protective role against $\mathrm{Hg}$ toxicity (Cuvin-Aralar and Furness, 1991) and an excess of $\mathrm{Hg}$ in relation to $\mathrm{Se}$ in the tissue is indicated by a $\mathrm{Hg}: \mathrm{Se}$ molar ratio $>1$ (Ralston et al., 2008). Molar ratios were assessed for both tissue types by converting measured concentrations to $\mathrm{nmol} \mathrm{g}^{-1}$ using the molecular weight of 200.59 for $\mathrm{Hg}$ and 78.96 for Se (Lischka et al., 2019a).

\section{Statistical analysis}

All statistical analyses were conducted with the software R (version 3.1.0, R Core Team, 2018). To assess whether size and sex influenced stable isotope values in the mantle tissue, analysis of covariance (ANCOVA) was performed on log-standardised $\delta^{13} \mathrm{C}$ and $\delta^{15} \mathrm{~N}$ values to check for interaction between size (ML), sex and $\delta^{15} \mathrm{~N} / \delta^{13} \mathrm{C}$ respectively. To test whether tissue type, size, $\delta^{13} \mathrm{C}$, $\delta^{15} \mathrm{~N}$ and/or sex influenced the trace element concentrations, generalised linear models (GLMs) with a negative binomial distribution and logit link function were applied (GLM, package 'MASS', Ripley et al., 2013). One model per trace element was fitted against non-transformed concentration and the variables were added sequentially; sex and size were added as an interaction term since females grow larger than males, confounding size as an independent variable. The variable sex was divided in three categories: females, large females (>400 mm) and males. Relationships between $\mathrm{Hg}$ and Se were assessed using pairwise nonparametric Spearman correlations ('corr.test' function of the 'corrgram' package, Wright, 2012). 
Results

The $\delta^{13} \mathrm{C}$ values were higher (sex; $\left.p<0.001\right)$ in females $(-19.6 \pm 1.1 \%$ ), followed by males $(-20.5 \pm$ $1.1 \%$ ), with size $(p<0.001)$ and $\delta^{15} \mathrm{~N}(p<0.001)$ showing significant effects (Fig. 2, Table S2). The $\delta^{15} \mathrm{~N}$ values were overall higher (sex; $\left.p<0.01\right)$ in females $(+11.5 \pm 1.3 \%)$, followed by males $(+10.6$ $\pm 1.3 \%$ o), with $\delta^{13} \mathrm{C}(p<0.01)$ showing a significant effect (Fig. 2, Table S2).

The trace element concentrations decreased in the following order: 1) in the digestive gland as Fe > $\mathrm{Cd}>\mathrm{Zn}>\mathrm{Cu}>\mathrm{Se}>\mathrm{As}>\mathrm{V}>\mathrm{Ag}>\mathrm{Pb}>\mathrm{Ni}>\mathrm{Hg}>\mathrm{Co}>\mathrm{Cr}$; and 2) in the mantle as $\mathrm{Zn}>\mathrm{Se}>\mathrm{Fe}>$ $\mathrm{As}>\mathrm{Cu}>\mathrm{V}>\mathrm{Ni}>\mathrm{Cd}>\mathrm{Hg}>\mathrm{Cr}>\mathrm{Ag}>\mathrm{Co}>\mathrm{Pb}($ Table 1$)$. The overall highest concentration for Cd was observed in the digestive gland of a male specimen (377 mm ML) with $1030 \mu \mathrm{g} \mathrm{g}^{-1} \mathrm{dw}$ (Table 1).

The Hg:Se molar ratio varied from 0.001 to 0.028 for both muscle and digestive gland. A significant positive relationship was detected between $\mathrm{Hg}$ and $\mathrm{Se}$ in the digestive gland $(R=0.80, p=0.001)$, but not in the mantle $(R=0.35, p=0.24)$.

Tissue type had a significant effect on $\mathrm{Ag}, \mathrm{Cd}, \mathrm{Cu}, \mathrm{Fe}, \mathrm{Hg}, \mathrm{Pb}$, and $\mathrm{Zn}$ concentrations according to the GLMs (Table 2). In both female and male specimens, concentrations of $\mathrm{Hg}$ and $\mathrm{Zn}$ were significantly higher in the mantle tissue, while $\mathrm{Ag}, \mathrm{Cd}, \mathrm{Cu}, \mathrm{Fe}$, and $\mathrm{Pb}$ concentrations were highest in the digestive gland (Table 1). In both tissues, size had a positive effect on $\mathrm{Ag}(p<0.001), \mathrm{Hg}(p<$ 0.001, Fig. 3), Se $(p<0.01)$ and $\mathrm{Zn}(p<0.001)$ concentrations, whereas a negative effect was observed for $\mathrm{Cd}(p<0.05)$ and $\mathrm{Pb}$ concentrations ( $p<0.001$, Table 2$)$. The digestive gland concentrations of $\mathrm{Pb}$ in smaller individuals of both sexes $(<200 \mathrm{~mm})$ were on average 3.1 times higher than those observed in larger individuals (Tables 1 and 2). The $\delta^{13} \mathrm{C}$ values had significant effects on $\mathrm{Ag}, \mathrm{Cd}$ (Fig. 4), Cu, $\mathrm{Pb}$ and $\mathrm{Zn}$ concentrations while $\delta^{15} \mathrm{~N}$ showed significant effects on $\mathrm{Cu}, \mathrm{Fe}, \mathrm{Pb}$ and $\mathrm{Zn}$ concentrations in both tissues (Table 2). Sex effects were observed for $\mathrm{Cd}, \mathrm{Cu}, \mathrm{Fe}(p<0.001)$ and $\mathrm{Zn}(p<0.05)$. The 
interaction term 'Sex $\times$ Size' showed a significant effect in $\mathrm{Cu}$ and $\mathrm{Zn}(p<0.001)$ concentrations (Table 2).

\section{Discussion}

The present study measured stable isotope values and trace element concentrations in one of the most abundant oegopsid squids in sub-Antarctic waters, the onychoteuthid $M$. ingens. Stable isotope values showed a large overlap, but also some differences, between sexes (Fig. 2), with large females having both higher $\delta^{13} \mathrm{C}$ and $\delta^{15} \mathrm{~N}$ values (Fig 2). On average, the values were similar to mantle tissue values of specimens sampled from the Kerguelen Islands (average $\delta^{13} \mathrm{C}:-20.1 \pm 0.4 \%$; $\delta^{15} \mathrm{~N}:+10.0 \pm 0.4 \%$; Cherel et al., 2008). Specimens sampled from shallower depths (168-285m) showed slightly higher $\delta^{13} \mathrm{C}\left(-18.59 \pm 0.76 \%\right.$ o), but similar $\delta^{15} \mathrm{~N}$ values $(+11.48 \pm 1.19 \%$; Rosas-Luis et al., 2016). The increased $\delta^{13} \mathrm{C}$ values could correspond to increased primary production in the shallower water layers (Faul et al., 2000), as the carbon signature is representative of the habitat of an individual (Chouvelon et al., 2011). The present results indicate that males and small-to-mid-sized females (ML 59-400 $\mathrm{mm}$ ) primarily forage in similar habitats, while larger females (ML >400 mm) occupy a different, deeper habitat, indicated by their positive $\delta^{15} \mathrm{~N}$ values. This result suggests that females move towards a deeper habitat with growth (Fig. 2). This ontogenetic migration in females, resulting in a change in diet, has been previously reported in this species (Jackson and Mladenov, 1994).

Similar to other oegopsids (e.g., Bustamante et al. 2008, Kojadinovic et al., 2011), most trace element concentrations were higher in the digestive gland than in the mantle tissue. The digestive gland can detoxify and store particular elements, such as $\mathrm{Ag}, \mathrm{Cd}, \mathrm{Cu}$, and Fe (Bustamante et al., 2002b, 2004; Finger and Smith, 1987; Penicaud et al., 2017; Rodrigo and Costa, 2017). This has been previously described in both non-ammoniacal squids Sthenoteuthis oualaniensis (Wu et al., 2017), S. pteropus (Lischka et al., 2018), Todarodes filippovae (Kojadinovic et al., 2011), and T. pacificus (Ichihashi et 
al., 2001), and ammoniacal squids such as $A$. $d u x$ (Bustamante et al., 2008) or ammonium-containing squids, e.g., Cranchia scabra, Galiteuthis armata, Helicocranchia pfefferi and Leachia atlantica, (Rafael, 2017). This suggests that ammonium metabolism may not have a major influence on global metal detoxification and storage strategies in squids. The digestive gland functioning is likely not affected by the buoyant ammonia stored in the muscular tissues (Voight et al., 1995). Despite a limited body of studies published on other squid families, our results suggest that bioaccumulation processes should be consistent across squid families.

\section{Cadmium}

The highest Cd concentrations were measured in the digestive gland of M. ingens (Table 2). Size had a negative effect on $\mathrm{Cd}$ concentrations and sex showed a significant effect, with the highest concentrations found in the digestive gland of males (Tables 1 and 2). A similar decrease in Cd concentrations with size has been observed in several other squid species including $L$. forbesi, $L$. vulgaris, T. sagittatus, and S. pteropus (e.g. Miramand et al., 2006, Dorneles et al., 2007, Chouvelon et al., 2011; Lischka et al., 2018), which could be explained by an ontogenetic diet shift toward prey with lower Cd concentrations (Lischka et al., 2018). Female M. ingens are believed to have a growth rate twice as high as males, and to migrate into deeper waters with maturity, possibly related to egg deposition (Jackson, 1997; Jackson et al., 2000), which could also contribute to the lowering of Cd (a dilution effect with size; Lischka et al., 2018). In contrast, this type of ontogenetic descent has not been observed for males so far. The difference in the Cd levels between the sexes could be related to a shift in habitat and correlated dietary shift (Arkhipkin and Laptikhovsky, 2010; Jackson et al., 1997), highlighted by the significantly different $\delta^{13} \mathrm{C}$ values (Fig. 4). Oceanic Cd concentrations vary across the Chatham Rise and the upwelling of low Cd sub-Antarctic waters to intermediate depths (200 $400 \mathrm{~m}$ ) has been previously suggested (Frew, 1995; Frew and Hunter, 1995). As sex-specific habitats 
are suggested by the $\delta^{13} \mathrm{C}$ values (Table 1), the bathypelagic feeding behaviour of female $M$. ingens could explain the lower $\mathrm{Cd}$ concentrations measured in specimens of this sex at a given size. Furthermore, in mature and spent (post-spawning) females, the mantle tissue degrades, resulting in a thin-walled mantle (Jackson and Mladenov, 1994). Spent females appear to cease feeding (Arkhipkin and Laptikhovsky, 2010), which could result in a reduced uptake of Cd through diet when compared to males.

Elevated Cd levels observed in Southern Ocean cephalopods have been linked to the Cd anomaly in subpolar systems (Bustamante et al., 1998b; Cipro et al., 2018). A study from the Kerguelen Islands (Cipro et al., 2018) reported similar Cd concentrations in whole $M$. ingens compared to the mean digestive gland concentrations reported in this study (with the exception of the high Cd concentrations measured in males, Table 1). Compared to other squids, the mean digestive gland Cd concentrations in the female specimens $\left(52.9 \pm 102.8 \mu \mathrm{g} \mathrm{g}^{-1} \mathrm{dw}\right)$ were comparable to concentrations measured in $T$. filippovae from Tasmania $\left(98.5 \pm 67.2 \mu \mathrm{g} \mathrm{g}^{-1} \mathrm{dw}\right.$, Kojadinovic et al., 2011) and $N$. sloanii from the Chatham Rise $\left(89.0 \pm 113.5 \mu \mathrm{g} \mathrm{g}^{-1} \mathrm{dw}\right.$, Lischka et al., 2020). In particular, male $M$. ingens exhibited similar Cd concentrations $\left(165.9 \pm 266.8 \mu \mathrm{g} \mathrm{g}^{-1} \mathrm{dw}\right)$ to those reported for other oceanic squids, which might support the different exposure level between males and females, probably linked to a sexspecific difference in habitat, as suggested by the differences in $\delta^{13} \mathrm{C}$ values. However, the $\delta^{15} \mathrm{~N}$ values do not support the effect of trophic magnification and further studies are needed to confirm this hypothesis.

Although the health effects of high Cd exposure for squids are not yet fully understood, Cd exposure has been linked to kidney and liver damage in humans and mammals (Gallien et al. 2001; Nicholson et al., 1983; Nicholson and Osborn, 1983). Some of the observed deleterious effects on cephalopods to date include altered digestive processes and/or increased oxidative stress on the embryonal development, as observed in the common cuttlefish Sepia officinalis or in the common octopus 
Octopus vulgaris (Lacoue-Labarthe et al., 2010a; Nicosia et al., 2015). Further research on the effects of Cd toxicity in cephalopods is needed to discuss our results in that respect.

\section{Mercury and selenium}

The mantle tissue of $M$. ingens had higher concentrations of $\mathrm{Hg}$ compared to the digestive gland (Tables 1 and 2). Observed $\mathrm{Hg}$ concentrations are consistent with previous studies on different squid species from the following families: Ommastrephidae, Onychoteuthidae, Gonatidae, Architeuthidae, and the myopsid family Loliginidae (Bustamante et al., 2000, 2008; Pierce et al., 2008). In cephalopods, $\mathrm{Hg}$ is mainly incorporated through the diet as methyl-Hg and might be partially demethylated in the digestive gland and excreted rapidly under its inorganic form (Lacoue-Labarthe et al., 2009). However, most of the $\mathrm{Hg}$ is redistributed to the muscular tissues, where it is stored as a result of the strong affinity of methyl-Hg for sulfhydryl protein groups (Bloom, 1992; Bustamante et al., 2006; Chouvelon et al., 2011). Therefore, $\mathrm{Hg}$ bioaccumulates with age in squid muscle tissue, which is reflected in the observed positive effect of size on $\mathrm{Hg}$ concentrations (Table 2, Fig. 2). In several cephalopod species, the bioaccumulation of $\mathrm{Hg}$ is also size-related, showing an increase with size (Bustamante et al., 2006). This has also been previously analysed in the curled octopus Eledone cirrhosa (Rossi et al., 1993) and the European flying squid T. sagittatus (Chouvelon et al., 2011). Other studies showed opposite trends, for example decreasing $\mathrm{Hg}$ concentrations with size were observed in L. vulgaris (Rjeibi et al., 2014) and Galiteuthis glacialis (Seco et al., 2020), whereas no effect of size on $\mathrm{Hg}$ concentrations was observed in Psychroteuthis glacialis (Seco et al., 2020). The Hg concentrations can be also enhanced by a shift in diet that occurs with growth (e.g., Barghigiani et al., 2000; Blum, 2011; Chouvelon et al., 2011); however, no shift in $\delta^{15} \mathrm{~N}$ (which would suggest a change in trophic position) was observed for M. ingens in the present study. Furthermore, deep-sea organisms have been reported to contain higher $\mathrm{Hg}$ concentrations relative to epipelagic animals 
(Chouvelon et al., 2012; Choy et al., 2017; Monteiro et al., 1996), which also contributes to an increased exposure of $\mathrm{Hg}$ for squids migrating towards deeper waters. Further investigations are needed to validate this hypothesis, including the use of stable isotopes of $\mathrm{Hg}$ (e.g., Blum et al., 2013; Renedo et al., 2018).

The positive correlation of $\mathrm{Hg}$ and Se concentrations in the digestive gland of $M$. ingens could indicate the involvement of $\mathrm{Se}$ in $\mathrm{Hg}$ detoxification processes, which has been previously proposed for fish (Yang et al., 2010), seabirds (Carravieri et al., 2017), and marine mammals (Cuvin-Aralar and Furness, 1991; Dietz et al., 2000). Although no mechanism of $\mathrm{Hg}$ and Se coprecipitation has yet been demonstrated in cephalopods, it has been proposed in O. vulgaris (Raimundo et al., 2010b). Selenium concentrations measured in the present study were overall comparable to those reported for $A$. $d u x$ (Bustamante et al., 2008) and T. filippovae (Kojadinovic et al., 2011). The positive size effect on Se concentrations (Table 2) strengthens the hypothesis of the involvement of this element in $\mathrm{Hg}$ detoxification, as the storage of both $\mathrm{Hg}$ and $\mathrm{Se}$ is dependent on growth and might highlight their similar bioaccumulation patterns.

Specimens of $M$. ingens from higher latitudes - e.g., from Macquarie Island $\left(54^{\circ} \mathrm{S}\right)$ — had slightly lower mean $\mathrm{Hg}$ concentrations (0.06-0.13 $\mu \mathrm{g} \mathrm{g} \mathrm{g}^{-1} \mathrm{dw}$; McArthur et al., 2003), compared to the specimens analysed in this study. Similarly, mantle concentrations of $\mathrm{Hg}$ in $M$. ingens from the Kerguelen Islands $\left(49^{\circ} \mathrm{S}\right)\left(0.11 \pm 0.08 \mu \mathrm{g} \mathrm{g}^{-1} \mathrm{dw}\right.$, Cipro et al., 2018) were slightly lower than those observed from the Chatham Rise $\left(40-43^{\circ} \mathrm{S}\right)$. Concentration differences could be linked to geochemical variation, since concentrations appear to vary with latitude in M. ingens. A latitudinal gradient in $\mathrm{Hg}$ concentrations has also been observed in seabirds (e.g., Pelecanoides urinatrix, D. exulans), with specimens from lower latitudes exhibiting lower concentrations when compared to higher-latitude specimens (Blévin et al., 2013; Carravieri et al., 2014, 2017, 2020). This effect could 
be explained by the increasing complexity in food webs with decreasing latitude (Carravieri et al., 2014, 2017). Thereby, the higher Hg concentrations in M. ingens from the Chatham Rise could be due to an increased complexity of the Chatham Rise food web when compared to the higher latitude food webs (e.g., Macquarie and Kerguelen Islands), or due to other factors, such as differences in primary productivity, which influence $\mathrm{Hg}$ concentrations in prey organisms, temperature and solar radiation (Carravieri, 2014; Fitzgerald et al., 2007). The subtropical front crosses the Chatham Rise and is known for its high primary productivity (Frew and Hunter, 1995), which could be reflected in the specimens' trace elemental concentrations. In the Chatham Rise individuals, the highest $\mathrm{Hg}$ concentrations were measured in female $M$. ingens $\left(2.42 \mu \mathrm{g} \mathrm{g}^{-1} \mathrm{dw}\right)$, and were higher than those reported in $N$. sloanii from the same area $\left(0.01-0.89 \mu \mathrm{g} \mathrm{g}^{-1} \mathrm{dw}\right.$, Lischka et al., 2020). This interspecies difference could be partly explained by different habitats, diets, sizes and/or physiology $-N$. sloanii is reported to generally occupy shallower waters (around $300 \mathrm{~m}$ ) than female M. ingens, which are found in deeper and colder waters (>800m, Arkhipkin and Laptikhovsky, 2010), a segregation corroborated by the the $\delta^{13} \mathrm{C}$ values observed in this study.

\section{Lead}

Overall, the highest $\mathrm{Pb}$ concentrations were measured in the digestive gland of male specimens (Tables 1, 2). Size had a significant negative effect on $\mathrm{Pb}$ concentrations, with smaller individuals exhibiting the highest $\mathrm{Pb}$ concentrations (Table 2). Both $\delta^{13} \mathrm{C}$ and $\delta^{15} \mathrm{~N}$ values also had significant effects on the $\mathrm{Pb}$ concentrations, suggesting that the $\mathrm{Pb}$ differences could be habitat related, linked to the ontogenetic descent observed in M. ingens (Arkhipkin and Laptikhovsky, 2010). Concentrations of $\mathrm{Pb}$ in the open ocean are predicted to reach their maximum concentrations in near-surface layers (Henderson and Maier-Reimer, 2002), where smaller individuals, including small males, feed (Arkhipkin and Laptikhovsky, 2010). In contrast, large female $M$. ingens tend to migrate to, and then reside in, deeper waters (Arkhipkin and Laptikhovsky, 2010; Jackson, 1997), where they might be 
exposed to lower $\mathrm{Pb}$ concentrations. In addition, $\mathrm{Pb}$ has been reported to bioreduce along the food web (Wang, 2002), with higher concentrations observed in individuals feeding at lower trophic levels, which aligns with the lower $\delta^{15} \mathrm{~N}$ values observed in males in this study (Tables 1,2 ). The cycling of $\mathrm{Pb}$ in New Zealand offshore waters remains understudied and future research on $\mathrm{Pb}$ concentrations found in different water layers and their associated fauna are necessary for understanding the bioaccumulation and distribution of this metal.

Silver

The concentrations of Ag were overall highest in the digestive gland (Tables 1,2), which suggests a high storage potential of this organ for Ag. Although few reports on Ag storage in cephalopods have been published, its duration appears to vary widely among groups, with a relatively short half-life of Ag [7 days] observed in the common cuttlefish Sepia officinalis (Bustamante et al., 2004). Concentrations of $\mathrm{Ag}$ in squid can reach high concentrations, which seems to indicate a stronger retention of this metal in their digestive gland when compared to the mantle tissue (e.g., A. dux, Bustamante et al., 2008; T. filippovae, Kojadinovic et al., 2011). In this study, both size and $\delta^{13} \mathrm{C}$ had a significant positive effect on Ag concentrations (Table 2); this could indicate that specimens are exposed to higher Ag concentrations as they migrate to greater depths, which are enriched in $\mathrm{Ag}$ (Zhang et al., 2004). Further investigations into the uptake, detoxification, and retention mechanisms of $\mathrm{Ag}$, as well as its distribution in pelagic waters, are needed to clarify these processes in squids.

Zinc

The tissue distribution of $\mathrm{Zn}$ found herein was comparable to that observed for the boreoatlantic armhook squid Gonatus fabricii, where Zn concentrations were higher in the mantle compared to the 
digestive gland tissue (Lischka et al., 2019a). Unbound $\mathrm{Zn}$ in the digestive gland cells is believed to induce metallothionein production, which plays an important part in the detoxification process of $\mathrm{Cd}$ in cephalopods (Bustamante et al., 2002b; Miramand and Bentley, 1992). Metallothionein has however been rarely quantified in cephalopods (see Bustamante et al., 2002a; Craig and Overnell, 2003; Raimundo, 2010a). The observed distribution pattern for $\mathrm{Zn}$, with higher concentrations in the mantle than digestive gland, could be explained as: 1) $\mathrm{Cd}$ and $\mathrm{Zn}$ may compete for binding sites in the digestive gland, and a stronger affinity of $\mathrm{Cd}$ to the binding sites could lead to a coaccumulation of $\mathrm{Zn}$; or 2) differences due to ammoniacal metabolism, which is supported by similar distribution pattern in the ammonium-containing C. scabra or L. atlantica (Rafael, 2017).

Larger female $M$. ingens individuals had higher $\mathrm{Zn}$ concentrations (Table 2), which could indicate a bioaccumulation pattern for this element. Similar relationships have been described in $A$. $d u x$ (Bustamante et al., 2008, ammoniacal) and G. fabricii (Lischka et al., 2019a, non-ammoniacal). In addition, $\mathrm{Zn}$ concentrations were affected by the interaction between sex and size, with larger females exhibiting higher $\mathrm{Zn}$ concentrations in the digestive gland relative to smaller males (Tables 1 and 2). This is consistent with $\mathrm{Zn}$ concentrations reported for mature Argentine shortfin squids (Illex argentinus, non-ammoniacal), where higher levels were observed in mature females than in mature males (Gerpe et al., 2000). The sex difference could be related to Zn cycling in the global oceans, where surface waters (and their associated fauna) exhibit lower concentrations compared to deeper waters (Conway and John, 2014; Lohan et al., 2002; Zhao et al., 2014). Because mature females of M. ingens are expected to feed in deeper waters (Jackson, 1997), they are more likely to be exposed to higher $\mathrm{Zn}$ concentrations from their diet. The significant effect of stable isotope values observed on $\mathrm{Zn}$ concentrations support this hypothesis. Another explanation could be that the maturation of the female gonads requires higher amounts of $\mathrm{Zn}$ for the synthesis of the vitellus, which results in a higher bioaccumulation of $\mathrm{Zn}$ (Lacoue-Labarthe et al., 2010b, 2016). Some essential elements (such as $\mathrm{Cu}$ and Zn) are reportedly deficient in the Southern Ocean (Petri and Zauke, 1993, Bustamante et al., 
1998b), which could result in a super accumulation of $\mathrm{Cd}$ at low $\mathrm{Cu}$ and $\mathrm{Zn}$ levels.

\section{Conclusion}

This study reports sex-specific differences in trace element concentrations in $M$. ingens from the Chatham Rise, New Zealand, with males exhibiting significantly higher Cd concentrations than females. Significant observed differences in $\delta^{13} \mathrm{C}$ values suggest that the $\mathrm{Cd}$ bioaccumulation in $M$. ingens is likely influenced by diet, with notable differences observed across different habitats. Large female $M$. ingens are known to migrate into deeper waters, where they likely consume less Cd-rich prey (i.e., fish) than males, which remain in shallower waters and feed on crustaceans known to be rich in Cd (Arkhipkin and Laptikhovsky, 2010). Overall, Cd concentrations in male M. ingens were comparable to those observed in both sexes of $N$. sloanii, from the same locality (Lischka et al., 2019b). Size showed significant effects on $\mathrm{Ag}, \mathrm{Hg}, \mathrm{Se}$, and $\mathrm{Zn}$ concentrations, which suggests that these elements bioaccumulate with growth. The high $\mathrm{Hg}$ concentrations measured in large females might indicate that their diet includes $\mathrm{Hg}$-enriched prey. Furthermore, the $\mathrm{Hg}$ concentrations measured in our female specimens from the Chatham Rise were higher than those observed in $N$. sloanii from the same location and in $M$. ingens from lower latitudes, which indicates a difference in habitat and diet. As has been reported in non-ammoniacal squids, trace element concentrations between the mantle and digestive gland of $M$. ingens differed. Overall, no clear trace element concentration differences between the ammoniacal $M$. ingens and non-ammoniacal squid species were observed, suggesting that the stored ammonium does not impact trace element bioaccumulation patterns. However, there is currently a paucity of trace element data for ammoniacal squids and further comparisons between the trace element-handling of ammoniacal and non-ammoniacal squid species is needed to confirm this hypothesis. Based on the measured $\mathrm{Cd}$ and $\mathrm{Hg}$ concentrations, $M$. ingens might represent a significant vector of these elements towards New Zealand's pelagic predators, since this species constitutes an important prey item. 


\section{Acknowledgments}

We would like to thank the team of the NIWA trawl survey funded by the New Zealand Ministry for Primary Industries and the crew of the RV Tangaroa for collecting the specimens. The authors are grateful to C. Churlaud and M. Brault-Favrou from the Plateforme Analyses Elémentaires of LIENSs for their support during the trace element analysis and to G. Guillou from the Plateforme Analyses Isotopiques of LIENSs for running the stable isotope analysis. Thanks are due to the CPER (Contrat de Projet Etat-Région) and the FEDER (Fonds Européen de Développement Régional) for funding the ICPs, the AMA, and the IRMS of LIENSs laboratory. The IUF (Institut Universitaire de France) is acknowledged for its support to PB as a Senior Member.

\section{References}

Arkhipkin, A. I., Laptikhovsky, V. V., 2010. Convergence in life-history traits in migratory deepwater squid and fish. ICES Journal of Marine Science, 67(7), 1444-1451.

Barghigiani, C., Ristori, T., Biagi, F., De Ranieri, S., 2000. Size related mercury accumulations in edible marine species from an area of the Northern Tyrrhenian Sea. Water, Air, \& Soil Pollution, 124, 169-176.

Blévin, P., Carravieri, A., Jaeger, A., Chastel, O., Bustamante, P., Cherel, Y., 2013. Wide range of mercury contamination in chicks of Southern Ocean seabirds. PLoS One, 8(1), e54508.

Bloom, N.S., 1992. On the chemical form of mercury in edible fish and marine invertebrate tissue. Canadian Journal of Fisheries and Aquatic Sciences, 49, 1010-1017.

Blum, J.D., 2011. Marine chemistry: Marine mercury breakdown. Nature Geoscience, 4(3), 139.

Blum, J.D., Popp, B.N., Drazen, J.C., Choy, C.A., Johnson, M.W., 2013. Methylmercury production below the mixed layer in the North Pacific Ocean. Nature Geoscience, 6(10), 879.

Bolstad, K.S., 2006. Sexual dimorphism in the beaks of Moroteuthis ingens Smith, 1881 (Cephalopoda: Oegopsida: Onychoteuthidae). New Zealand Journal of Zoology, 33, 317-327.

Bolstad, K.S., Braid, H.E., Strugnell, J.M., Lindgren, A.R., Lischka, A., Kubodera, T., Laptikhovsky, V.L., Labiaga, A.R., 2018. A mitochondrial phylogeny of the family Onychoteuthidae (Cephalopoda: Oegopsida). Molecular Phylogenetics and Evolution, 128, 88-97.

Boyle, P., Rodhouse, P., 2005. Cephalopods as prey. Cephalopods-Ecology and Fisheries. 
Blackwell Publishing, Oxford, 234-258.

Brooks, R.R., Rumsey, D., 1974. Heavy metals in some New Zealand commercial sea fishes. New Zealand Journal of Marine and Freshwater Research, 8, 155-166.

Bryan, G.W., 1984. Pollution due to heavy metals and their compounds. Marine Ecology 5, 12891431.

Bustamante, P., Caurant, F., Fowler, S.W., Miramand, P., 1998a. Cephalopods as a vector for the transfer of cadmium to top marine predators in the north-east Atlantic Ocean. Science of the Total Environment, 220, 71-80.

Bustamante, P., Cherel, Y., Caurant, F., Miramand, P., 1998b. Cadmium, copper and zinc in octopuses from Kerguelen Islands, Southern Indian Ocean. Polar Biology, 19, 264-271.

Bustamante, P., Grigioni, S., Boucher-Rodoni, R., Caurant, F., Miramand, P., 2000. Bioaccumulation of 12 trace elements in the tissues of the nautilus Nautilus macromphalus from New Caledonia. Marine Pollution Bulletin, 8, 688-696.

Bustamante, P., Cosson, R.P., Gallien, I., Caurant, F., Miramand, P., 2002a. Cadmium detoxification processes in the digestive gland of cephalopods in relation to accumulated cadmium concentrations. Marine Environmental Research, 53, 227-241.

Bustamante, P., Teyssié, J.-L., Fowler, S.W., Cotret, O., Danis, B., Miramand, P., Warnau, M., $2002 b$. Biokinetics of zinc and cadmium accumulation and depuration at different stages in the life cycle of the cuttlefish Sepia officinalis. Marine Ecology Progress Series, 231, 167-177.

Bustamante, P., Bocher, P., Cherel, Y., Miramand, P., Caurant, F., 2003. Distribution of trace elements in the tissues of benthic and pelagic fish from the Kerguelen Islands. Science of the Total Environment, 313(1-3), 25-39.

Bustamante, P., Teyssié, J.-L., Danis, B., Fowler, S., Miramand, P., Cotret, O., Warnau, M., 2004. Uptake, transfer and distribution of silver and cobalt in tissues of the common cuttlefish Sepia officinalis at different stages of its life cycle. Marine Ecology Progress Series, 269, 185-195.

Bustamante, P., Lahaye, V., Durnez, C., Churlaud, C., Caurant, F., 2006. Total and organic Hg concentrations in cephalopods from the North Eastern Atlantic waters: influence of geographical origin and feeding ecology. Science of the Total Environment, 368, 585-596.

Bustamante, P., González, A.F., Rocha, F., Miramand, P., Guerra, A., 2008. Metal and metalloid concentrations in the giant squid Architeuthis dux from Iberian waters. Marine Environmental Research, 66, 278-287.

Carravieri, A., Bustamante, P., Tartu, S., Meillère, A., Labadie, P., Budzinski, H., Peluhet, L., Barbraud, C., Weimerskirch, H., Chastel, O., Cherel, Y., 2014. Wandering albatrosses 
document latitudinal variations in the transfer of persistent organic pollutants and mercury to Southern Ocean predators. Environmental Science \& Technology, 48(24), 14746-14755.

Carravieri, A., Cherel, Y., Brault-Favrou, M., Churlaud, C., Peluhet, L., Labadie, P., Budzinski, H., Chastel, O., Bustamante, P., 2017. From Antarctica to the subtropics: Contrasted geographical concentrations of selenium, mercury, and persistent organic pollutants in skua chicks (Catharacta spp.). Environmental Pollution, 228, 464-473.

Carravieri, A., Bustamante, P., Labadie, P., Budzinski, H., Chastel, O., Cherel, Y., 2020. Trace elements and persistent organic pollutants in chicks of 13 seabird species from Antarctica to the subtropics. Environment International, 134, 105225.

Carter, L., 1980. New Zealand region bathymetry 1:6000000 (2nd ed.). New Zealand Oceanographic Institute Chart, Miscellaneous Series, 15, Wellington, New Zealand.

Cherel, Y., Duhamel, G., 2003. Diet of the squid Moroteuthis ingens (Teuthoidea: Onychoteuthidae) in the upper slope waters of the Kerguelen Islands. Marine Ecology Progress Series, 250, 197 203.

Cherel, Y., Ducatez, S., Fontaine, C., Richard, P., Guinet, C., 2008. Stable isotopes reveal the trophic position and mesopelagic fish diet of female southern elephant seals breeding on the Kerguelen Islands. Marine Ecology Progress Series, 370, 239-247.

Cherel, Y., Xavier, J.C., de Grissac, S., Trouvé, C., Weimerskirch, H., 2017. Feeding ecology, isotopic niche, and ingestion of fishery-related items of the wandering albatross Diomedea exulans at Kerguelen and Crozet Islands. Marine Ecology Progress Series, 565, 197-215.

Cherel, Y., Barbraud, C., Lahournat, M., Jaeger, A., Jaquemet, S., Wanless, R.M., Phillips, R.A., Thompson, D.R., Bustamante, P., 2018. Accumulate or eliminate? Seasonal mercury dynamics in albatrosses, the most contaminated family of birds. Environmental Pollution, $241,124-135$.

Chouvelon, T., Spitz, J., Cherel, Y., Caurant, F., Sirmel, R., Mèndez-Fernandez, P., Bustamante, P., 2011. Inter-specific and ontogenetic differences in $\delta^{13} \mathrm{C}$ and $\delta^{15} \mathrm{~N}$ values and $\mathrm{Hg}$ and $\mathrm{Cd}$ concentrations in cephalopods. Marine Ecology Progress Series, 433, 107-120.

Chouvelon, T., Spitz, J., Caurant, F., Mèndez-Fernandez, P., Autier, J., Lassus-Débat, A., Chappuis, A., Bustamante, P., 2012. Enhanced bioaccumulation of mercury in deep-sea fauna from the Bay of Biscay (north-east Atlantic) in relation to trophic positions identified by analysis of carbon and nitrogen stable isotopes. Deep-Sea Research, 65, 113-124.

Choy, C.A., Haddock, S.H., Robison, B.H., 2017. Deep pelagic food web structure as revealed by in situ feeding observations. Proceedings of the Royal Society B: Biological Sciences, 284, 
20172116.

Cipro, C.V., Cherel, Y., Bocher, P., Caurant, F., Miramand, P., Bustamante, P., 2018. Trace elements in invertebrates and fish from Kerguelen waters, southern Indian Ocean. Polar Biology, 41, $175-191$.

Clarke, M.R., Roper, C.F.E., 1998. Cephalopods represented by beaks in the stomach of a sperm whale stranded at Paekakariki, North Island, New Zealand. African Journal of Marine Science, 20, 129-133.

Conway, T.M., John, S.G., 2014. The biogeochemical cycling of zinc and zinc isotopes in the North Atlantic Ocean. Global Biogeochemical Cycles, 28, 1111-1128.

Craig, S., Overnell, J., 2003. Metals in squid, Loligo forbesi, adults, eggs and hatchlings. No evidence for a role for $\mathrm{Cu}$-or $\mathrm{Zn}$-metallothionein. Comparative Biochemistry and Physiology Part C: Toxicology \& Pharmacology, 134(3), 311-317.

Cuvin-Aralar, M.L.A., Furness, R.W., 1991. Mercury and selenium interaction: a review. Ecotoxicology and Environmental Safety, 21, 348-364.

de la Chesnais, T., Fulton, E.A., Tracey, S.R., Pecl, G.T., 2019. The ecological role of cephalopods and their representation in ecosystem models. Reviews in Fish Biology and Fisheries, 29, $313-334$

Dietz, R., Riget, F., Born, E.W., 2000. An assessment of selenium to mercury in Greenland marine animals. Science of the Total Environment, 245, 15-24.

Dorneles, P.R., Lailson-Brito, J., dos Santos, R.A., da Costa, P.A.S., Malm, O., Azevedo, A.F., Torres, J.P.M., 2007. Cephalopods and cetaceans as indicators of offshore bioavailability of cadmium off Central South Brazil Bight. Environmental Pollution, 148(1), 352-359.

Eagles-Smith, C.A., Silbergeld, E.K., Basu, N., Bustamante, P., Diaz-Barriga, F., Hopkins, W.A., Kidd, K.A., Nyland, J.F., 2018. Modulators of mercury risk to wildlife and humans in the context of rapid global change. Ambio, 47(2), 170-197.

Eisler, R., 2009. Compendium of Trace Metals and Marine Biota: Volume 1: Plants and Invertebrates. Elsevier.

Faul, K.L., Ravelo, A.C., Delaney, M.L., 2000. Reconstructions of upwelling, productivity, and photic zone depth in the eastern equatorial Pacific Ocean using planktonic foraminiferal stable isotopes and abundances. Journal of Foraminiferal Research, 30, 110-125.

Finger, J.M., Smith, J.D., 1987. Molecular association of $\mathrm{Cu}, \mathrm{Zn}, \mathrm{Cd}$ and ${ }^{210} \mathrm{Po}$ in the digestive gland of the squid Nototodarus gouldi. Marine Biology, 95, 87-91.

Fisher, N.S., Reinfelder, J.R., 1995. The trophic transfer of metals in marine systems. Metal 
Speciation and Bioavailability in Aquatic Systems, 3, 407-411.

Fitzgerald, W.F., Lamborg, C.H., Hammerschmidt, C.R., 2007. Marine biogeochemical cycling of mercury. Chemical reviews, 107(2), 641-662.

Frew, R.D., 1995. Antarctic bottom water formation and the global cadmium to phosphorus relationship. Geophysical Research Letters, 22, 2349-2352.

Frew, R.D., Hunter, K.A., 1995. Cadmium-phosphorus cycling at the subtropical convergence south of New Zealand. Marine Chemistry, 51, 223-237.

Gallien I., Caurant F., Bordes M., Bustamante P., Miramand P., Fernandez B., Quellard N., Babin P. (2001). Cadmium-containing granules in kidney tissue of the Atlantic white-sided dolphin (Lagenorhyncus acutus) off the Faroe Islands. Comparative Biochemistry and Physiology Part C: Pharmacology, Toxicology and Endocrinology, 130: 389-395.

Gault-Ringold, M., Adu, T., Stirling, C.H., Frew, R.D., Hunter, K.A., 2012. Anomalous biogeochemical behavior of cadmium in subantarctic surface waters: mechanistic constraints from cadmium isotopes. Earth and Planetary Science Letters, 341, 94-103.

Gerpe, M.S., de Moreno, J.E.A., Moreno, V.J., Patat, M.L., 2000. Cadmium, zinc and copper accumulation in the squid Illex argentinus from the Southwest Atlantic Ocean. Marine Biology, 136, 1039-1044.

Green, K., Burton, H.R., 1993. Comparison of the stomach contents of southern elephant seals, Mirounga leonina, at Macquarie and Heard Islands. Marine Mammal Science, 9, 10-22.

Henderson, G.M., Maier-Reimer, E., 2002. Advection and removal of ${ }^{210} \mathrm{~Pb}$ and stable $\mathrm{Pb}$ isotopes in the oceans: a general circulation model study. Geochimica et Cosmochimica Acta, 66, 257272.

Ibánez, C.M., Keyl, F., 2010. Cannibalism in cephalopods. Reviews in Fish Biology and Fisheries, 20, 123-136.

Ichihashi, H., Kohno, H., Kannan, K., Tsumura, A., Yamasaki, S., 2001. Multielemental Analysis of Purpleback Flying Squid Using High Resolution Inductively Coupled Plasma-Mass Spectrometry (HR ICP-MS). Environmental Science \& Technology, 35, 3103-3108.

Jackson, G.D., 1995. The use of beaks as tools for biomass estimation in the deepwater squid Moroteuthis ingens (Cephalopoda: Onychoteuthidae) in New Zealand waters. Polar Biology, $15,9-14$.

Jackson, G.D., 1997. Age, growth and maturation of the deepwater squid Moroteuthis ingens (Cephalopoda: Onychoteuthidae) in New Zealand waters. Polar Biology, 17, 268-274.

Jackson, G. D., George, M. J., Buxton, N. G., 1998. Distribution and abundance of the squid 
Moroteuthis ingens (Cephalopoda: Onychoteuthidae) in the Falkland Islands region of the South Atlantic. Polar Biology, 20(3), 161-169.

Jackson, G.D., Mladenov, P.V., 1994. Terminal spawning in the deepwater squid Moroteuthis ingens (Cephalopoda: Onychoteuthidae). Journal of Zoology, 234, 189-201.

Jackson, G.D., Shaw, A.G.P., Lalas, C., 2000. Distribution and biomass of two squid species off southern New Zealand: Nototodarus sloanii and Moroteuthis ingens. Polar Biology, 23, 699705 .

Jöst, C., Zauke, G.-P., 2008. Trace metal concentrations in Antarctic sea spiders (Pycnogonida, Pantopoda). Marine Pollution Bulletin, 56, 1396-1399.

Keil, S., De Broyer, C., Zauke, G.-P., 2008. Significance and interspecific variability of accumulated trace metal concentrations in Antarctic benthic crustaceans. International Review of Hydrobiology, 93, 106-126.

Kojadinovic, J., Jackson, C.H., Cherel, Y., Jackson, G.D., Bustamante, P., 2011. Multi-elemental concentrations in the tissues of the oceanic squid Todarodes filippovae from Tasmania and the southern Indian Ocean. Ecotoxicology and Environmental Safety, 74, 1238-1249.

Lacoue-Labarthe, T., Metian, M., Warnau, M., Oberhänsli, F., Rouleau, C., Bustamante, P., 2009. Biokinetics of $\mathrm{Hg}$ and $\mathrm{Pb}$ accumulation in the encapsulated egg of the common cuttlefish Sepia officinalis: radiotracer experiments. Science of the Total Environment, 407, 6188-6195.

Lacoue-Labarthe, T., Le Bihan, E., Borg, D., Koueta, N., Bustamante, P., 2010a. Acid phosphatase and cathepsin activity in cuttlefish (Sepia officinalis) eggs: the effects of $\mathrm{Ag}, \mathrm{Cd}$, and $\mathrm{Cu}$ exposure. ICES Journal of Marine Science, 67(7), 1517-1523.

Lacoue-Labarthe, T., Warnau, M., Oberhänsli, F., Teyssié, J.L., Bustamante, P., 2010b. Contrasting accumulation biokinetics and distribution of 241Am, Co, Cs, Mn and $\mathrm{Zn}$ during the whole development time of the eggs of the common cuttlefish, Sepia officinalis. Journal of Experimental Marine Biology and Ecology, 382(2), 131-138.

Lacoue-Labarthe, T., Nunes, P.A., Ziveri, P., Cinar, M., Gazeau, F., Hall-Spencer, J.M., Hilmi, N., Moschella, P., Safa, A., Sauzade, D., Turley, C., 2016. Impacts of ocean acidification in a warming Mediterranean Sea: An overview. Regional Studies in Marine Science, 5, 1-11.

Langston, W.J., 2017. Toxic effects of metals and the incidence of metal pollution in marine ecosystems, in: Heavy Metals in the Marine Environment. CRC Press, 101-120.

Lischka, A., Lacoue-Labarthe, T., Hoving, H.J.T., JavidPour, J., Pannell, J.L., Merten, V., Churlaud, C., Bustamante, P., 2018. High cadmium and mercury concentrations in the tissues of the orange-back flying squid, Sthenoteuthis pteropus, from the tropical Eastern Atlantic. 
Ecotoxicology and Environmental Safety, 163, 323-330.

Lischka, A., Lacoue-Labarthe, T., Bustamante, P., Piatkowski, U., Hoving, H.J.T., 2019a. Trace element analysis reveals bioaccumulation in the squid Gonatus fabricii from polar regions of the Atlantic Ocean. Environmental Pollution, 256, 113389.

Lischka, A., Pook, C.J., Bolstad, K.S.R., Pannell, J.L., Braid, H.E., 2019b. Metal composition of arrow squid (Nototodarus sloanii [Gray 1849]) from the Chatham Rise, New Zealand: implications for human consumption. Environmental Science and Pollution Research, 26(12), $11978-11987$.

Lischka, A., Pook, C.J., Pannell, J.L., Braid, H.E., Gaw, S., Bolstad, K.S.R., 2020. Distribution of trace elements in the tissues of arrow squid (Nototodarus sloanii) from the Chatham Rise, New Zealand: Human health implications. Fisheries Research, 221, 105383.

Lohan, M.C., Statham, P.J., Crawford, D.W., 2002. Total dissolved zinc in the upper water column of the subarctic North East Pacific. Deep Sea Research Part II: Topical Studies in Oceanography, 49, 5793-5808.

Lu, C.C., Williams, R., 1994. Kondakovia longimana Filippova, 1972 (Cephalopoda: Onychoteuthidae) from the Indian Ocean sector of the Southern Ocean. Antarctic Science, $6(2), 231-234$.

Lucia, M., Strøm, H., Bustamante, P., Gabrielsen, G.W., 2016. Trace element concentrations in relation to the trophic behaviour of endangered Ivory Gulls (Pagophila eburnea) during their stay at a breeding site in Svalbard. Archives of Environmental Contamination and Toxicology, $71,518-529$.

Lyver, P.O.B., Aldridge, S.P., Gormley, A.M., Gaw, S., Webb, S., Buxton, R.T., Jones, C.J., 2017. Elevated mercury concentrations in the feathers of grey-faced petrels (Pterodroma gouldi) in New Zealand. Marine Pollution Bulletin, 119, 195-203.

Martin, J.H., Flegal, A.R., 1975. High copper concentrations in squid livers in association with elevated levels of silver, cadmium, and zinc. Marine Biology, 30, 51-55.

McArthur, T., Butler, E.C., Jackson, G.D., 2003. Mercury in the marine food chain in the Southern Ocean at Macquarie Island: an analysis of a top predator, Patagonian toothfish (Dissostichus eleginoides) and a mid-trophic species, the warty squid (Moroteuthis ingens). Polar Biology, $27,1-5$.

McClatchie S, Dunford A., 2003. Estimated biomass of vertically migrating mesopelagic fish off New Zealand. Deep Sea Research Part I: Oceanographic Research Papers, 50(10-11), 1263-81.

Miramand, P., Bentley, D., 1992. Concentration and distribution of heavy metals in tissues of two 
cephalopods, Eledone cirrhosa and Sepia officinalis from the French coast of the English Channel. Marine Biology, 114, 407-414.

Miramand, P., Bustamante, P., Bentley, D., Kouéta, N., 2006. Variation of heavy metal concentrations ( $\mathrm{Ag}, \mathrm{Cd}, \mathrm{Co}, \mathrm{Cu}, \mathrm{Fe}, \mathrm{Pb}, \mathrm{V}$, and $\mathrm{Zn}$ ) during the life cycle of the common cuttlefish Sepia officinalis. Science of the Total Environment, 361, 132-143.

Monteiro, L.R., Costa, V., Furness, R.W., Santos, R.S., 1996. Mercury concentrations in prey fish indicate enhanced bioaccumulation in mesopelagic environments. Marine Ecology Progress Series, 141, 21-25.

Murphy, R.J., Pinkerton, M.H., Richardson, K.M., Bradford-Grieve, J.M., Boyd, P.W., 2001. Phytoplankton distributions around New Zealand derived from SeaWiFS remotely-sensed ocean colour data. New Zealand Journal of Marine and Freshwater Research, 35, 343-362.

Nicholson, J.K., Kendall, M.D., Osborn, D., 1983. Cadmium and mercury nephrotoxicity. Nature, $304,633$.

Nicholson, J.K., Osborn, D., 1983. Kidney lesions in pelagic seabirds with high tissue levels of cadmium and mercury. Journal of Zoology, 200, 99-118.

Nicosia, A., Salamone, M., Mazzola, S., Cuttitta, A., 2015. Transcriptional and biochemical effects of cadmium and manganese on the defense system of Octopus vulgaris paralarvae. BioMed Research International, 2015,437328, https://doi.org/10.1155/2015/437328.

Northern, T.J., Smith, A.M., McKinnon, J.F., Bolstad, K.S., 2019. Trace elements in beaks of greater hooked squid Onykia ingens: opportunities for environmental tracing. Molluscan Research, 39, 29-34.

Penicaud, V., Lacoue-Labarthe, T., Bustamante, P., 2017. Metal bioaccumulation and detoxification processes in cephalopods: A review. Environmental Research, 155, 123-133.

Petri, G., Zauke, G.-P., 1993. Trace metals in crustaceans in the Antarctic Ocean. Ambio-Journal of Human Environment Research and Management, 22, 529-536.

Pierce, G.J., Stowasser, G., Hastie, L.C., Bustamante, P., 2008. Geographic, seasonal and ontogenetic variation in cadmium and mercury concentrations in squid (Cephalopoda: Teuthoidea) from UK waters. Ecotoxicology and Environmental Safety, 70, 422-432.

Pinkerton, M.H., 2011. A balanced trophic model of the Chatham Rise, New Zealand. Unpublished NIWA report. https://niwa.co.nz/sites/niwa.co.nz/files/chatham-model_32.pdf (accessed: $6^{\text {th }}$ Nov 2019).

Probert, P.K., McKnight, D.G., 1993. Biomass of bathyal macrobenthos in the region of the Subtropical Convergence, Chatham Rise, New Zealand. Deep Sea Research Part I: 
Oceanographic Research Papers, 40, 1003-1007.

R Core Team, 2018. R: A language and environment for statistical computing. R Foundation for Statistical Computing, Vienna, Austria. URL https://www.R-project.org/.

Rafael, A.P.M.-H., 2017. Contaminants in deep-sea glass squids (Cranchiidae) from the eastern tropical Atlantic oxygen minimum zone. Universidade de Lisboa, Portugal (Master Thesis).

Raimundo, J., Costa, P. M., Vale, C., Costa, M. H., Moura, I., 2010a. Metallothioneins and trace elements in digestive gland, gills, kidney and gonads of Octopus vulgaris. Comparative Biochemistry and Physiology Part C: Toxicology \& Pharmacology, 152(2), 139-146.

Raimundo, J., Vale, C., Canário, J., Branco, V., Moura, I., 2010b. Relations between mercury, methyl-mercury and selenium in tissues of Octopus vulgaris from the Portuguese Coast. Environmental Pollution, 158, 2094-2100.

Rainbow, P.S., 1995. Biomonitoring of heavy metal availability in the marine environment. Marine Pollution Bulletin, 31, 183-192.

Ralston, N.V., Ralston, C.R., Blackwell III, J.L., Raymond, L.J., 2008. Dietary and tissue selenium in relation to methylmercury toxicity. Neurotoxicology, 29, 802-811.

Renedo, M., Amouroux, D., Pedrero, Z., Bustamante, P., Cherel, Y., 2018. Identification of sources and bioaccumulation pathways of $\mathrm{MeHg}$ in subantarctic penguins: a stable isotopic investigation. Scientific Reports, 8(1), 8865.

Ripley, B., Venables, B., Bates, D.M., Hornik, K., Gebhardt, A., Firth, D., Ripley, M.B., 2013. Package 'mass.' Cran R.

Rjeibi, M., Metian, M., Hajji, T., Guyot, T., Chaouacha-Chékir, R.B., Bustamante, P., 2014. Interspecific and geographical variations of trace metal concentrations in cephalopods from Tunisian waters. Environmental Monitoring and Assessment, 186, 3767-3783.

Rodrigo, A.P., Costa, P.M., 2017. The Role of the Cephalopod Digestive Gland in the Storage and Detoxification of Marine Pollutants. Frontiers in Physiology, 8, 232.

Rosas-Luis, R., Sánchez, P., Portela, J.M., del Rio, J.L., 2014. Feeding habits and trophic interactions of Doryteuthis gahi, Illex argentinus and Onykia ingens in the marine ecosystem off the Patagonian Shelf. Fisheries Research, 152, 37-44.

Rosas-Luis, R., Navarro, J., Sánchez, P., Del Río, J.L., 2016. Assessing the trophic ecology of three sympatric squid in the marine ecosystem off the Patagonian Shelf by combining stomach content and stable isotopic analyses. Marine Biology Research, 12, 402-411.

Rossi, A., Pellegrini, D., Belcari, P., Barghigiani, C., 1993. Mercury in Eledone cirrhosa from the northern Tyrrhenian sea: Contents and relations with life cycle. Marine Pollution Bulletin, 26, 
$683-686$.

Seco, J., Xavier, J.C., Brierley, A.S., Bustamante, P., Coelho, J.P., Gregory, S., Fielding, S., Pardal, M.A., Pereira, B., Stowasser, G., 2019. Mercury levels in Southern Ocean squid: Variability over the last decade. Chemosphere, 239, 124785.

Smith, E., 1881. Account of the Zoological Collections made during the Survey of HMS 'Alert'in the Straits of Magellan and on the Coast of Patagonia., in: Proceedings of the Zoological Society of London. Wiley Online Library, pp. 2-141.

Tchounwou, P.B., Yedjou, C.G., Patlolla, A.K., Sutton, D.J., 2012. Heavy metal toxicity and the environment, in: Molecular, Clinical and Environmental Toxicology. Springer, pp. 133-164.

Voight, J.R., Pörtner, H.O., O'Dor, R.K., 1995. A review of ammonia-mediated buoyancy in squids (cephalopoda: Teuthoidea). Marine and Freshwater Behaviour and Physiology, 25(1-3), 193203.

Wang, W.-X., Fisher, N.S., 1998. Accumulation of trace elements in a marine copepod. Limnology and Oceanography, 43, 273-283.

Wang, W.X., 2002. Interactions of trace metals and different marine food chains. Marine Ecology Progress Series, 243, 295-309.

Whyte, A.L., Hook, G.R., Greening, G.E., Gibbs-Smith, E., Gardner, J.P., 2009. Human dietary exposure to heavy metals via the consumption of greenshell mussels (Perna canaliculus Gmelin 1791) from the Bay of Islands, northern New Zealand. Science of the Total Environment, 407, 4348-4355.

Wright, K. (2012). Corrgram: Plot a correlogram [computer program]. R package version 1.4.

Wu, Y.Y., Shen, Y., Huang, H., Yang, X.Q., Zhao, Y.Q., Cen, J.W., Qi, B., 2017. Trace Element Accumulation and Tissue Distribution in the Purpleback Flying Squid Sthenoteuthis oualaniensis from the Central and Southern South China Sea. Biological Trace Element Research, 175(1), 214-222.

Xavier, J., Rodhouse, P., Purves, M., Daw, T., Arata, J., Pilling, G., 2002. Distribution of cephalopods recorded in the diet of the Patagonian toothfish (Dissostichus eleginoides) around South Georgia. Polar Biology, 25, 323-330.

Yang, D.-Y., Xu, Y., Chen, Y.-W., Belzile, N., 2010. Inverse relationships between selenium and mercury in tissues of young walleye (Stizosedion vitreum) from Canadian boreal lakes. Science of the Total Environment, 408, 1676-1683.

Zauke, G.-P., Savinov, V.M., Ritterhoff, J., Savinova, T., 1999. Heavy metals in fish from the Barents Sea (summer 1994). Science of the Total Environment, 227, 161-173. 
Zhang, Y., Obata, H., Nozaki, Y., 2004. Silver in the Pacific Ocean and the Bering Sea. Geochemical Journal, 38(6), 623-633.

Zhao, Y., Vance, D., Abouchami, W., De Baar, H.J., 2014. Biogeochemical cycling of zinc and its isotopes in the Southern Ocean. Geochimica et Cosmochimica Acta, 125, 653-672. 


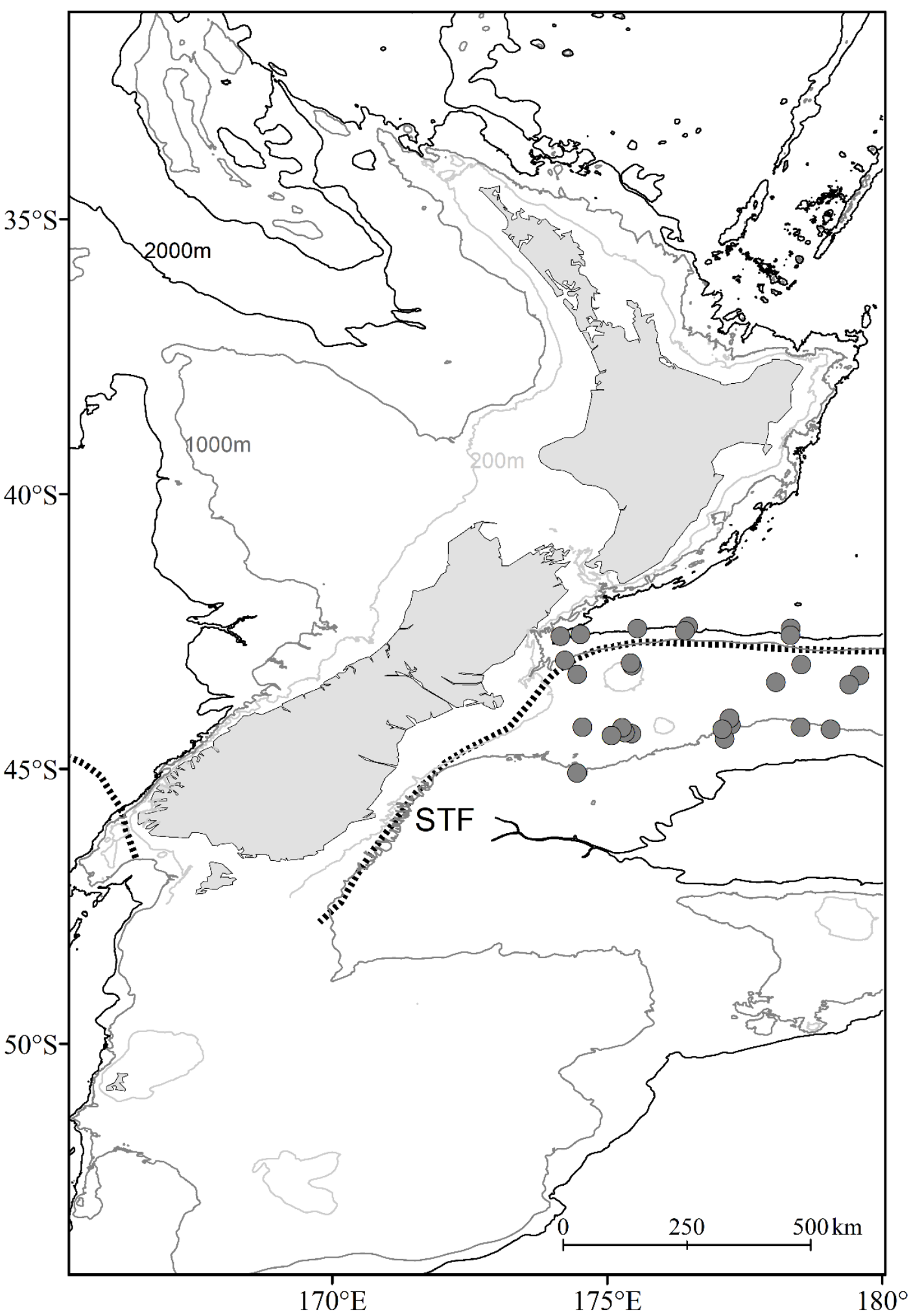

Figure 1. Map of the Chatham Rise showing sampling stations of the Moroteuthopsis ingens specimens analysed in the present study. Depth bars include $200 \mathrm{~m}, 1000 \mathrm{~m}$ and $200 \mathrm{~m}$. The subtropical front (STF) is indicated by a dashed line. 
a)

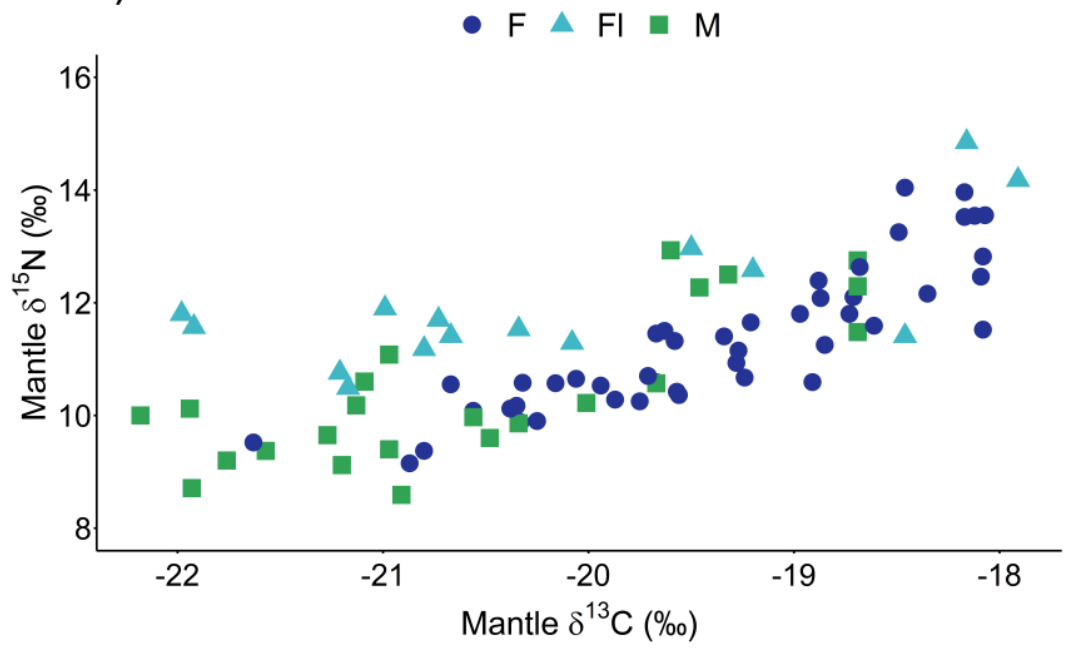

b)

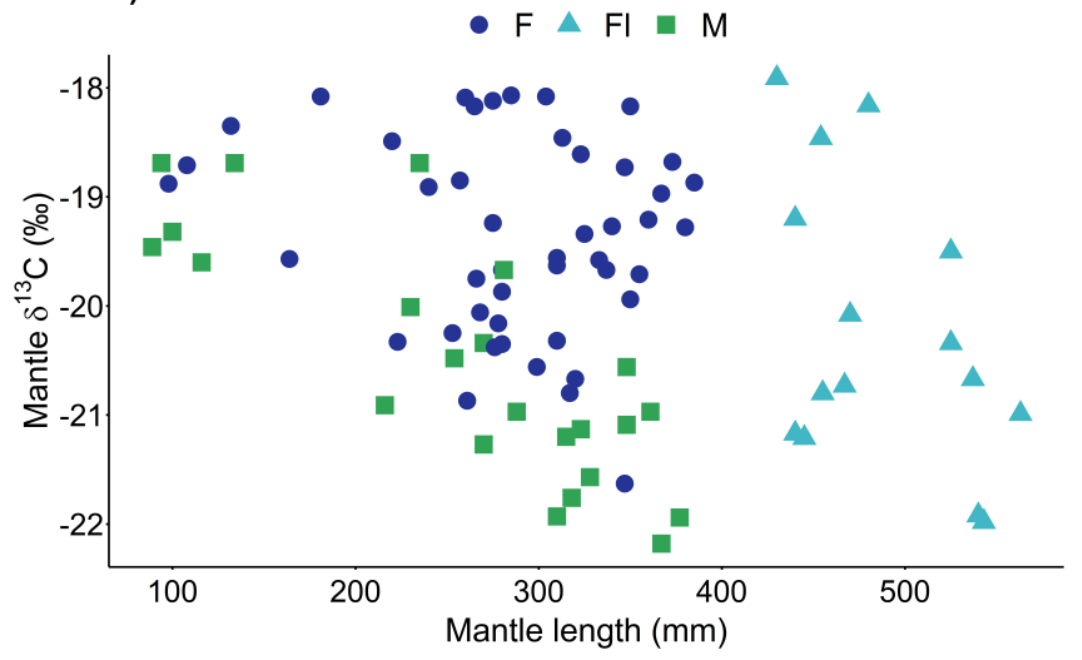

c)

- $F \triangle F I \| M$



Figure 2. Relationship between a.) $\delta^{13} \mathrm{C}$ and $\delta^{15} \mathrm{~N}$, b.) mantle length (mm) and $\delta^{13} \mathrm{C}$, and c.) Size and $\delta^{15} \mathrm{~N}$ in the mantle tissue of female (F, $\left.\mathrm{n}=44\right)$, large female $(\mathrm{Fl}>400 \mathrm{~mm}, \mathrm{n}=15)$ and male (M, n=25) M. ingens from the Chatham Rise, New Zealand. 


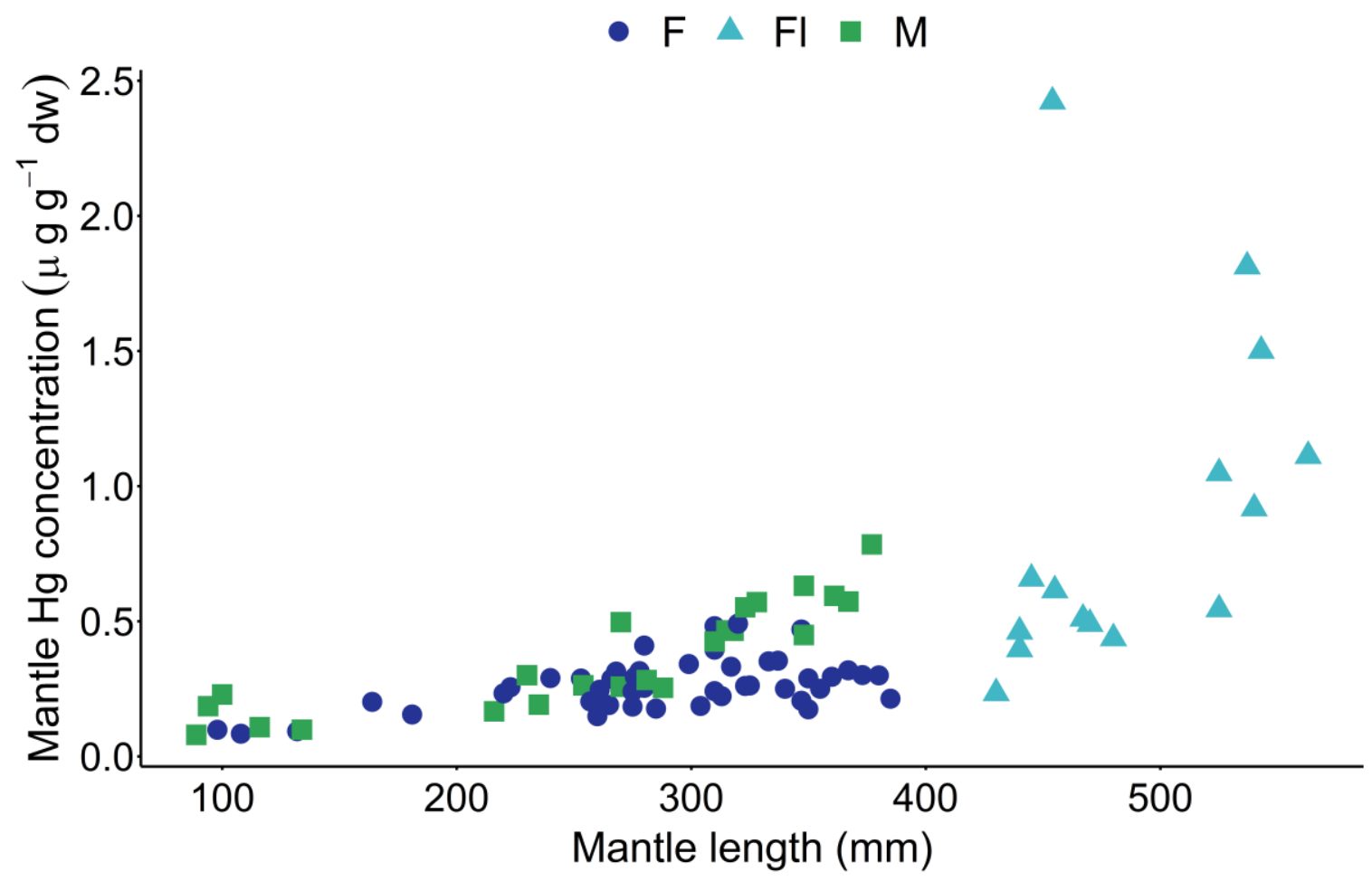

Figure 3. Relationship between mantle length ( $\mathrm{mm}$ ) and $\mathrm{Hg}$ concentrations (in $\mu \mathrm{g} \cdot \mathrm{g}^{-1} \mathrm{dw}$ ) in the mantle tissue of female ( $\mathrm{F}, n=44)$, large female (Fl>400 mm, $n=15)$ and male $(\mathrm{M}, n=25) M$. ingens from the Chatham Rise, New Zealand. 
a)

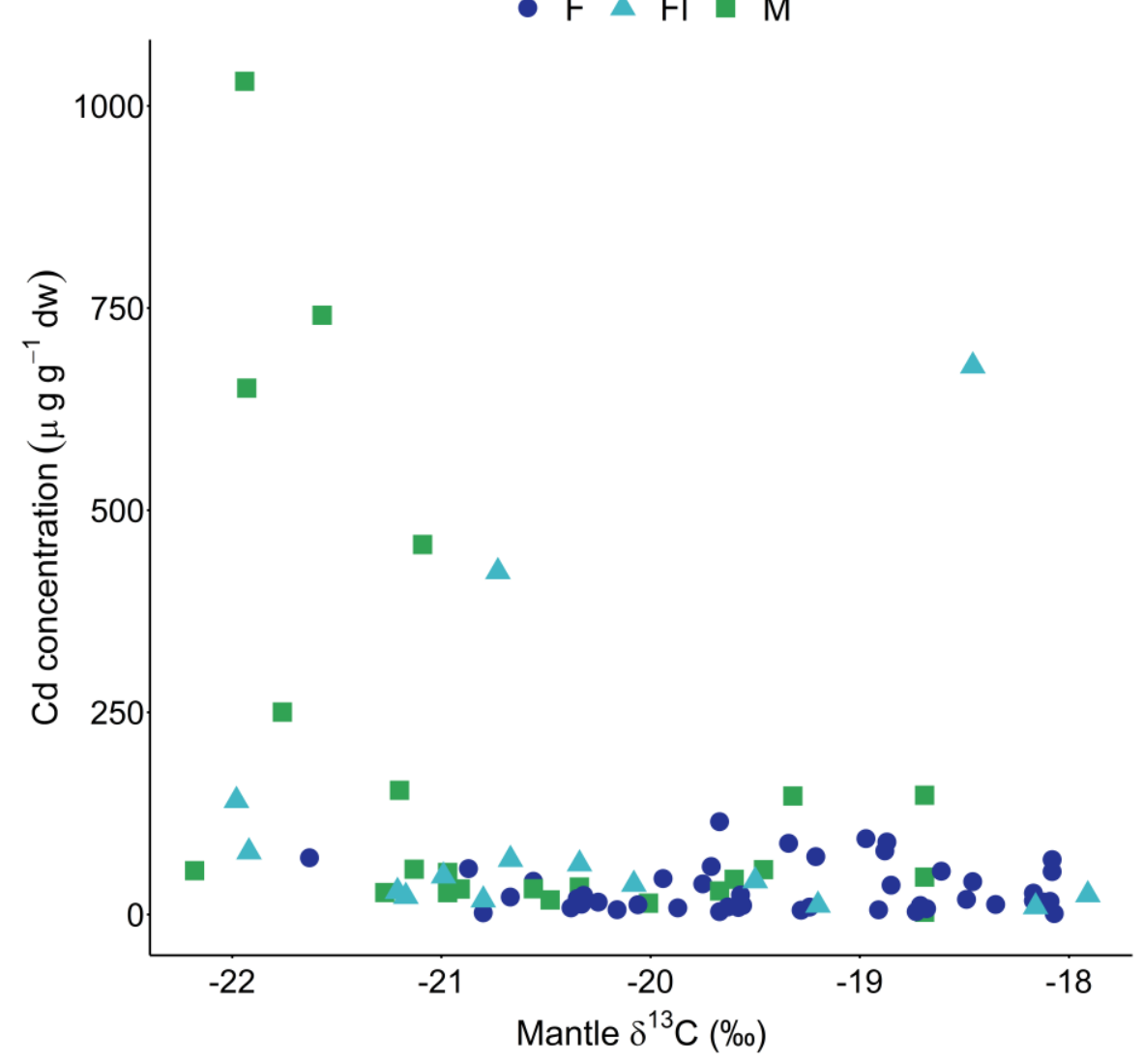

b)

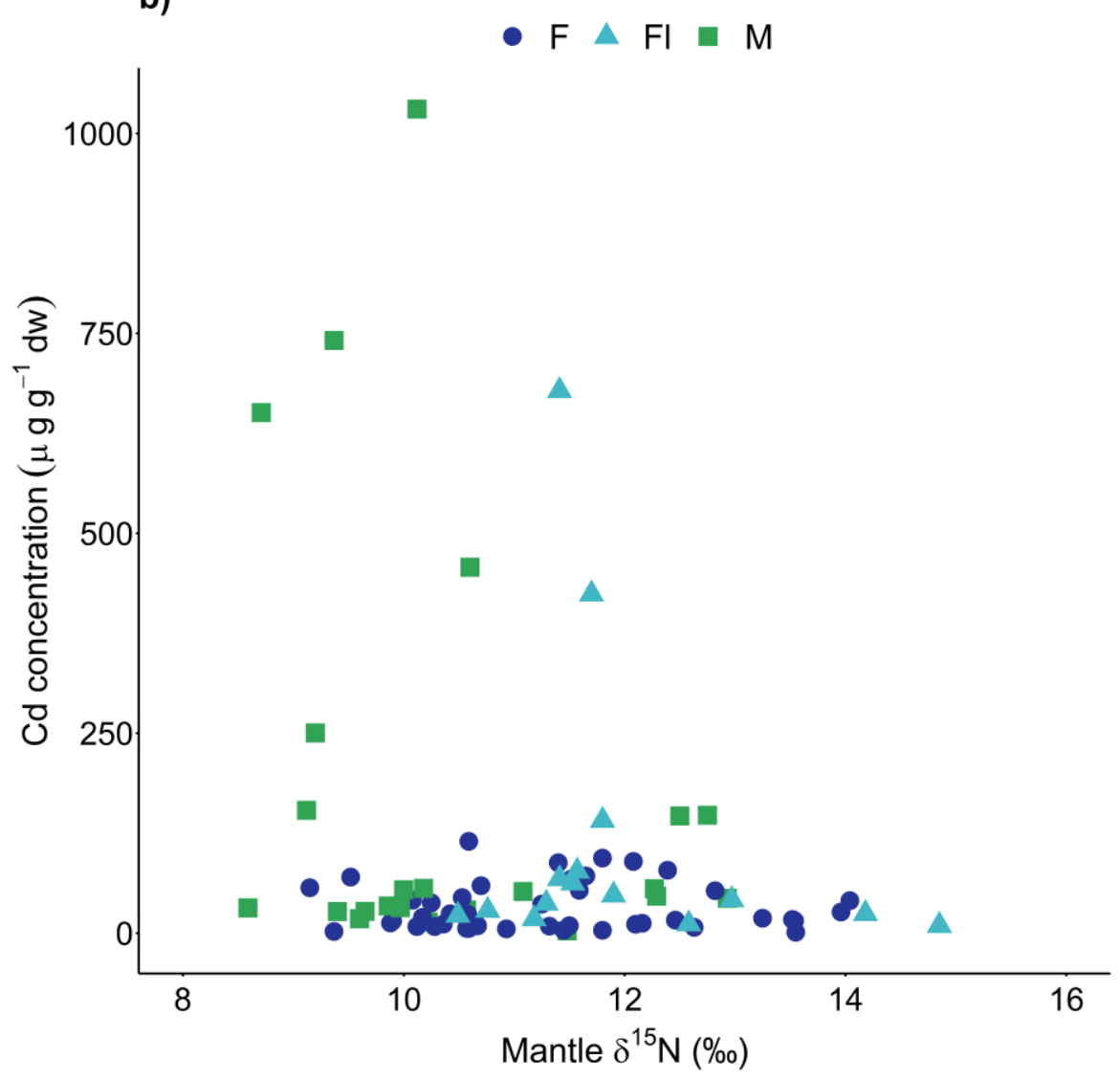

Figure 4. Relationship between Cd concentration (in $\mu \mathrm{g} \cdot \mathrm{g}^{-1} \mathrm{dw}$ ) in the digestive gland and a.) $\delta^{13} \mathrm{C}$ and b.) $\delta^{15} \mathrm{~N}$ in the tissues of female $(\mathrm{F}$, $n=44)$, large female ( $\mathrm{Fl}>400 \mathrm{~mm}, n=15)$ and male $(\mathrm{M}, n=25)$ M. ingens from the Chatham Rise, New Zealand. 
Table 1. Trace element concentrations (mean \pm standard deviation [SD], minimum, and maximum) in the digestive gland and mantle tissue, and stable isotope ratios $\left(\delta^{13} \mathrm{C}, \delta^{15} \mathrm{~N}\right)$ from the mantle tissue of Moroteuthopsis ingens from the Chatham Rise, New Zealand. Concentrations are given in $\mu \mathrm{g} \mathrm{g}^{-1} \mathrm{dw}$ and stable isotope values are expressed in \%o.

\begin{tabular}{|c|c|c|c|c|c|c|c|c|}
\hline \multirow[b]{2}{*}{ Element } & \multicolumn{2}{|c|}{ † Digestive gland $(n=59)$} & \multicolumn{2}{|c|}{$\widehat{o}$ Digestive gland $(n=25)$} & \multicolumn{2}{|c|}{ q Mantle $(n=59)$} & \multicolumn{2}{|c|}{ ô Mantle $(n=25)$} \\
\hline & mean \pm SD & $\min -\max$ & mean $\pm S D$ & min-max & mean \pm SD & $\min -\max$ & mean \pm SD & $\min -\max$ \\
\hline $\mathrm{Ag}$ & $1.63 \pm 1.62$ & $0.02-7.69$ & $2.29 \pm 2.06$ & $0.07-10.72$ & $0.04 \pm 0.04$ & $0.01-0.23$ & $0.06 \pm 0.04$ & $0.01-0.31$ \\
\hline As & $11.10 \pm 1.71$ & $10.23-16.91$ & $12.59 \pm 2.03$ & $10.29-14.9$ & $13.66 \pm 3.40$ & $10.30-21.08$ & $12.48 \pm 2.58$ & $10.25-16.75$ \\
\hline $\mathrm{Cd}$ & $52.90 \pm 103$ & $0.94-678$ & $166 \pm 267$ & $2.70-1030$ & $0.57 \pm 0.51$ & $0.11-2.06$ & $0.99 \pm 0.75$ & $0.10-2.56$ \\
\hline Co & $0.15 \pm 0.13$ & $0.01-0.67$ & $0.17 \pm 0.11$ & $0.06-0.54$ & $0.06 \pm 0.02$ & $0.03-0.15$ & $0.07 \pm 0.04$ & $0.04-0.16$ \\
\hline $\mathrm{Cr}$ & $0.11 \pm 0.03$ & $0.10-0.23$ & $0.12 \pm 0.03$ & $0.10-0.20$ & $0.15 \pm 0.13$ & $0.10-0.64$ & $0.13 \pm 0.06$ & $0.10-0.31$ \\
\hline $\mathrm{Cu}$ & $29.84 \pm 63.76$ & $2.88-424$ & $28.38 \pm 34.92$ & $4.86-176$ & $8.37 \pm 4.05$ & $3.71-28.01$ & $11.79 \pm 7.46$ & $4.27-32.99$ \\
\hline $\mathrm{Fe}$ & $233 \pm 216$ & $59.81-1514$ & $264 \pm 182$ & $88.38-833$ & $17.94 \pm 26.98$ & $4.65-173$ & $24.15 \pm 29.93$ & $6.07-136$ \\
\hline $\mathrm{Hg}$ & $0.19 \pm 0.23$ & $0.06-1.43$ & $0.17 \pm 0.10$ & $0.07-0.54$ & $0.42 \pm 0.41$ & $0.08-2.42$ & $0.37 \pm 0.19$ & $0.08-0.78$ \\
\hline $\mathrm{Ni}$ & $0.63 \pm 0.66$ & $0.04-3.54$ & $0.62 \pm 0.41$ & $0.04-1.94$ & $0.81 \pm 0.24$ & $0.49-1.64$ & $0.93 \pm 0.44$ & $0.49-2.39$ \\
\hline $\mathrm{Pb}$ & $0.32 \pm 0.62$ & $0.01-3.07$ & $0.82 \pm 1.50$ & $0.01-4.71$ & $0.04 \pm 0.04$ & $0.01-0.27$ & $0.03 \pm 0.02$ & 0.01-0.09 \\
\hline $\mathrm{Se}$ & $26.78 \pm 12.57$ & $20.44-65.67$ & $28.16 \pm 8.97$ & $18.15-49.43$ & $26.75 \pm 7.72$ & $20.49-42.15$ & $24.28 \pm 5.54$ & $20.50-32.24$ \\
\hline V & $2.19 \pm 0.33$ & $2.04-3.38$ & $2.44 \pm 0.40$ & $2.06-2.98$ & $2.56 \pm 0.74$ & $2.04-4.21$ & $2.43 \pm 0.55$ & $2.05-3.22$ \\
\hline $\mathrm{Zn}$ & $44.55 \pm 26.80$ & $15.57-169$ & $42.65 \pm 12.25$ & $26.34-76.19$ & $66.88 \pm 12.30$ & $42.27-105$ & $69.16 \pm 15.05$ & $55.03-106$ \\
\hline$\delta^{13} \mathrm{C}$ & NA & $\mathrm{NA}$ & $\mathrm{NA}$ & NA & $-19.57 \pm 1.08$ & $-21.98--17.91$ & $-20.47 \pm 1.08$ & $-22.10--18.69$ \\
\hline$\delta^{15} \mathrm{~N}$ & NA & NA & NA & NA & $+11.47 \pm 1.28$ & $+9.15-14.85$ & $+10.57 \pm 1.34$ & $+8.59-12.93$ \\
\hline
\end{tabular}


Table 2. Output of the generalised linear models (GLMs), illustrating variables that significantly influence the trace element concentrations of $M$. ingens from the Chatham Rise, New Zealand. The $p$-values of the variables are shown according to likelihood ratio tests (*** $0.001, * * 0.01, * 0.05)$. Negative $(\downarrow)$ and positive $(\uparrow)$ effects for the continuous variable size are indicated with arrows $(\uparrow \uparrow \uparrow 0.001, \uparrow \uparrow 0.01, \uparrow 0.05)$.

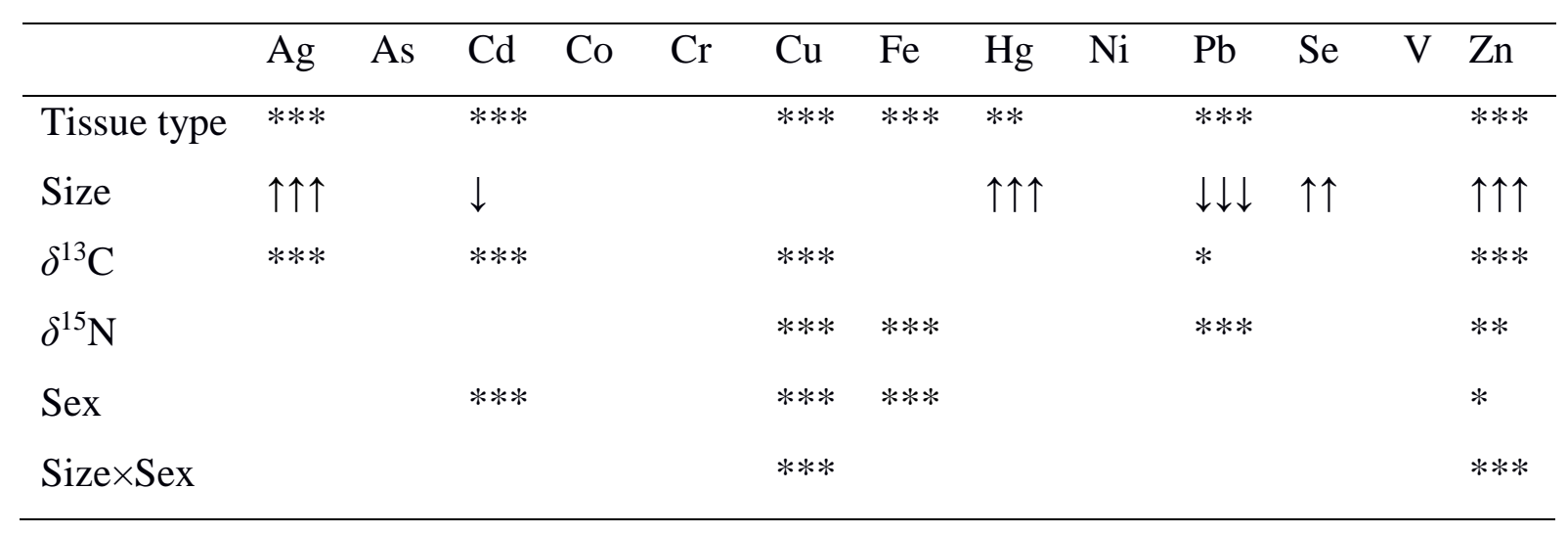




\section{Supplementary Materials}

Table S3. Number of M. ingens specimens analysed from the Chatham Rise, New Zealand, according to their size classes (Mantle length, ML). Large females were classified as $>400 \mathrm{~mm}$.

\begin{tabular}{lll}
\hline Size class ML $[\mathrm{mm}]$ & Female $(n)$ & Male $(n)$ \\
\hline$<100$ & 1 & 2 \\
$100-200$ & 4 & 3 \\
$200-300$ & 19 & 8 \\
$300-400$ & 22 & 12 \\
$>400$ & 13 & \\
\hline
\end{tabular}

Table S2. Analysis of covariance (ANCOVA) table for the linear models fitted for the $\delta^{13} \mathrm{C}$ and $\delta^{15} \mathrm{~N}$ values of the mantle tissue of $M$. ingens from the Chatham Rise, New Zealand. Df - degrees of freedom. Asterisks indicate the level of significance: $* \mathrm{p}<0.05 * * \mathrm{p}<0.01 * * * \mathrm{p}<0.001$.

\begin{tabular}{|c|c|c|c|c|c|}
\hline & Df & Sum of squares & Mean square & F value & Significance \\
\hline \multicolumn{6}{|c|}{$\delta^{13} \mathrm{C}$} \\
\hline Size & 1 & 2.11 & 2.11 & 34.37 & $* * *$ \\
\hline Sex & 2 & 5.38 & 2.69 & 43.72 & $* * *$ \\
\hline$\delta^{15} \mathrm{~N}$ & 1 & 8.40 & 8.40 & 136.57 & $* * *$ \\
\hline Residuals & 79 & 4.86 & 0.06 & & \\
\hline \multicolumn{6}{|c|}{$\delta^{15} \mathbf{N}$} \\
\hline Size & 1 & 0.07 & 0.07 & 0.96 & \\
\hline Sex & 2 & 4.66 & 2.33 & 30.37 & $* * *$ \\
\hline$\delta^{13} \mathrm{C}$ & 1 & 9.95 & 9.95 & 129.59 & $* * *$ \\
\hline Residuals & 79 & 6.07 & 0.08 & & \\
\hline
\end{tabular}

